\title{
Ribanın Tarifi Konusunda Yeni Bir Yaklaşım Önerisi*
}

Servet BAYINDIR ${ }^{* *}$

\begin{abstract}
Öz
Faiz tarihin hemen her döneminde tartışılmış iktisadi bir sorundur. Bu tartışmalarda faizin tanımı ve gerekçesi belirleyici olmuştur. Gerek İslam kaynaklarında gerekse batılı kaynaklarda faizin çok farklı tanımları yapılmıştır. Bu makalede, literatürde yaygın olarak kabul edilen tanımların konuyu tüm açıklığıyla ortaya koyamadığı, bu durumun çağımızdaki birçok faizli işlemin ticaret gibi algılanması ve pazarlanması sonucunu doğurduğu ileri sürülmektedir. Dolaysıyla yeni bir faiz tanımına ihtiyaç duyulduğu açıktır. Bu varsayımdan hareketle faiz için alternatif tanım teklifinde bulunulmaktadır. Riba Kur'an'da sadaka, zekât, karz ve özellikle bey' ile mukayeseli şekilde ele alınır ve ribanın yapı itibariyle bu varlık transfer yöntemlerinden farklı olduğu vurgulanır. Kur'an'da ve sünnette kastedilen riba, tarihi süreçte bilinen ve uygulanan ribadır. Ribanın Cahiliye (Kur'an ribası) ve sünnet (fadl) ribası şeklindeki ayrımını isabetli görmüyoruz. Zira nasslarda riba farklı yönleriyle bir bütün olarak ifade edilmektedir. Klasik kaynaklarda riba genelde "muamelede şart koşulan karşılıksız fazlalık" yahut "karşılıksız fazlalı̆̆ın şart koşulduğ u akit" şeklinde hukuki yaklaşımlarla tanımlanmıştır. Her iki tanımda da ribanın eylemsel yönüne değil hukuki bir bakış açısıyla hâsılat, fazlalık, sonuç tarafına vurgu yapılmıştır. Bu durum Batılı literatürde de benzer niteliktedir. Ribanın sadece fazlalığa odaklı hukuksal tarifi işin eylemsel tarafının gözlerden kaçması sonucunu doğurmuştur. Bunun bir neticesi olarak tarihte ve günümüzde çok sayıda işlemin özü itibariyle riba olmasına rağmen farklı ve masum ad ve kılıflarla uygulanması ve böylece insanlığın aldatılması durumu ortaya çıkmıştır. Ribanın etimolojik olarak doğru konumlandırılması, İslam'dan önceki dönemde nasıl kullanıldığı, hangi anlamlara geldiğinin
\end{abstract}

\footnotetext{
* Araştırma Makalesi. Makale Gönderim Tarihi: 16.04.2021 Makale Kabul Tarihi: 22.06.2021

Bu çalışma İSIFFAM ve İKAM tarafından Sakarya' da 1-2 Nisan 2017 tarihinde düzenlenen “İslam İktisadı Perspektifinden Faiz" adlı çalıştayda sunulan ve İslam İktisadı Perspektifinden Faiz ed. Taha Eğri -Zeynep Hafsa Orhan (İstanbul: İktisat Yay., 2018) adlı kitapta yer verilen "Faizin Tanımı Meselesi, 53-69" ayrıca Kur'an Araştırmaları Vakfı (KURAV) tarafından 21-22 Nisan 2018 tarihlerinde Bursa'da "İktisadi Hayatta ve İslam'da Faiz (Uluslararası Faiz Çalıştayı)" adıyla düzenlenen çalıştayda sunulan ve İktisadi Hayatta ve İslam'da Faiz ed. Recep Cici-Süleyman Sayar (İstanbul: Ensar Neşriyat, 2018) adıyla yayınlanan kitapta yer verilen “Kur'an ve Sünnet Açısından Faiz (Cahiliye ve Asr-1 Saadet), 287-318” adlı tebliğlerin gözden geçirilerek geliştirilmiş şeklinden ibarettir.

DOI: https://doi.org/10.52886/ilak.917477

** Prof. Dr., İstanbul Üniversitesi, İlahiyat Fakültesi, İslam Hukuku Anabilim Dalı

Prof. Dr., Istanbul University, Faculty of Divinity, Department of Islamic Law

servetbayindir@hotmail.com ORCID: 0000-0003-4435-5455
} 
bilinmesi, ayrıca İslam'ın bu kavrama yüklediği farklı anlam ve içeriklerin doğru anlaşılmasının, konunun doğru zemine oturtulmasına katkı sağlayacağı kanaatindeyiz.

Anahtar Kelimeler: Faiz, Riba, Ribh, Kâr, Bey', Ticaret.

\title{
A New Approach Proposal on The Definition of Riba
}

\begin{abstract}
Interest is an economic problem that has been discussed in almost every period of history. The definition and justification of interest has been decisive in this process. Various definitions of interest have been made in Islamic and western sources. In this article, it is argued that the definitions that are widely accepted and used in the literature do not fully reveal the subject, and this situation results in the perception and marketing of many interest-bearing transactions in our age as trading. Therefore, it is emphasized that a new definition of interest is needed. Based on this assumption, an alternative definition of interest is proposed. In the Qur'an, riba is compared with sadaqa, zakat, qard and especially bay' and it is emphasized that riba is different from these asset transfer methods in terms of structure. Since riba is a method known and applied in every period of history, riba that is meant in the Qur'an and sunnah is riba that is known and practiced in the historical process. We do not consider the distinction of riba as Jahiliyya (riba of Qur'an) and sunnah (riba of fadl) appropriate. Because riba is expressed as a whole in different aspects in the scriptures. In classical sources, riba is generally defined with legal approaches as "unrequited surplus stipulated in the transaction" or "contract where unrequited surplus is stipulated". In both definitions, the emphasis is not on the operational aspect of riba, but on the revenue, surplus and result side from a legal point of view. This situation is similar in Western literature. The legal definition of riba, which focuses only on excess, has resulted in the fact that the operational side of the work is overlooked. As a result of this, many transactions in history and today, although they are riba in essence, are applied with different and innocent names and covers, thus deceiving humanity. We believe that the etymologically correct positioning of riba, how it was used in the pre-Islamic period, knowing what it means, and understanding the different meanings and contents that Islam ascribes to this concept will contribute to placing the subject on the right ground.
\end{abstract}

Keywords: Interest, Riba, Ribh, Profit, Bay', Trade.

\section{Özet}

Riba (faiz) geçmişte olduğu gibi günümüzde de iktisadi niteliği ve fikhî hükmü hakkındaki tartışmalar açısından güncelliğini korumaktadır. Günümüz Türkçesinde riba yerine faiz kelimesi yaygın olarak kullanılmaktadır. Biz de bu metinde yer yer riba yer yer de aynı anlama gelmek üzere faizi kullanacağız. Faiz hâlihazırda hem iktisadi ve finansal hayatın önemli unsurlarından birini oluşturmakta hem de tanımı, muhtevası, çeşitleri, iktisadi ve sosyal hayata etkileri, dini, hukuki ve ahlaki niteliği bakımından farklı bilim dallarının gündemini meşgul 
etmektedir. Faizcilik İslam öncesi din ve düşünce sistemlerinde olduğu gibi İslam'da da meşru görülmeyen; kaçınılması, uzak durulması emredilen bir davranış biçimidir. Ayrıca Yahudilik ve Hıristiyanlığın kutsal metinlerinde konuya yaklaşım tarzını kısaca inceleyeceğiz. Bu minvalde ribanın Kur'an ve sünnette geçtiği anlamlar, ribanın diğer bir takım varlık transfer yöntemleri ile birleştiği ve ayrıştı̆̆ı noktalar kısaca ele alınıp çağımızda riba yasağının esnetilmesine/gevşetilmesine yönelik olduğunu düşündügümüz bazı uygulamalara eleştiriler getirilecektir. Son olarak, fıkıh kaynaklarındaki ve dolayısıyla günümüzdeki yaygın riba tanımının Kur'an ve sünnette yer verilen ve insanlık tarihi boyunca bilinen ve uygulanan ribayı tam olarak değil de eksik olarak karşıladığı ve bu durumun mevcut riba uygulamalarının olumsuz sonuçlarının dikkatlerden kaçmasına yol açtığı gerekçesinden hareketle mevcut tanıma ek olarak farklı bir riba tanımı teklifinde bulunulacaktır. Kur'an ve sünnette riba ayrıntılı olarak ortaya konulmuş olup riba kelimesinin Kur'an ve sünnetteki kullanımı ona yüklenebilecek terim anlamı hususunda önemli ipuçları içermektedir. Kur'an ve sünnette riba çok farklı kalıp ve anlamlarda geçer. Bu kullanımların etimolojik olarak incelenmesi riba kelimesinin anlaşılmasına farklı anlamlar yüklenip yüklenmediğinin anlaşılması açısından önem arz etmektedir. Bu kullanımlardan yola çıklarak tarihi süreçte çeşitli riba teorileri geliştirilmiş, riba ile ilgili zengin bir birikim oluşmuştur. Biz bu çalışmada özellikle ribanın tarifi konusuna odaklanacağız. Ancak, konuya zemin oluşturması bakımından Kur'an'da ve sünnette ribanın ele alınış biçimi, ona yüklenen anlam çeşitliliği, başka mal mübadele yöntemleriyle mukayese edilişi ve fıkıhta ribanın tanımı konusunda ileri sürülen görüşlere temas edeceğiz. Bu bağlamda Riba kelimesi ile sadece ismin değil aynı zamanda fiilin, iktisadi eylemin de kastedildiği sonucu yalnızca yukarıda zikredilen kelimelerden çıkmaz, aynı zamanda ribanın diğer bir kısım iktisadi davranış biçimleri, mal mübadelesi yöntemleri ile mukayese edildiği örneklerden de anlaşılır. Ancak genelde fazlalığa/isme odaklanıldığından kelimenin eylemsel anlamı gözlerden kaçmaktadır. Mal mübadelesi ise hükmü açısından meşru ve gayri meşru, doğası/teknik yapısı itibariyle de bedelli ve bedelsiz olabilir. Ribanın geçtiği ayetlerde, riba hem bedelsiz hem de bedelli mal mübadele yöntemlerinden birkaçı ile mukayeseli şekilde ortaya konulmuştur. Bu mukayeselerden, ribanın fazlalık anlamındaki isim haline ek olarak, bir kısım özellikleri ile diğer mübadele yöntemlerinden ayrılan, nev-i şahsına münhasır, gayri meşru nitelikli bir bedelli mal mübadele yöntemi (eylem) olduğu sonucu da çıkar. Bu mal transfer yöntemlerinden ivazsız nitelikli olan sadaka/zekât ve karz konusuna mukayese açısından kısaca temas edip daha sonra ivazlı mal mübadelesi yöntemi olan bey' ile ribayı karşılaştırıp tanıma geçeceğiz. Ayrıca riba ile karz arasındaki benzerlik ve farklılıklara değineceğiz. Bu bağlamda riba ile karzın ayrıştığı nokta bunları veren kişinin menfaat elde edip etmemesidir. Karzın asıl meşru kılınış amacından çıkarılıp veren açısından kazanç aracı haline getirilmesi durumunda işlem karz olmaktan çıkıp ribaya dönüşür. Çünkü ribada da ancak karz gibi mislî ve tüketilir 
nitelikli mallar başkasının mülkiyetine geçirilmekte; risk karşı tarafa yüklenmekte, vade geldiğinde başta verilen malın bir benzeri -karzdan farklı olarak- belli oranda fazlası ile geri talep edilmektedir. İşte bu durum, yani karzda verilen mala ek olarak bir farkın talep edilmesi, işlemi karz olmaktan çıkarıp "riba" karakterine büründürmektedir. Nasıl ki bedelsiz olarak âriyet verilen maldan ücret talep edildiğinde işlem "ücretli ariyet" olarak kalmayıp “icare”ye dönüşmekte, bir başkasına vedia olarak bırakılan mislî mal tüketildiğinde akit vedia olmaktan çıkıp karza dönüşmekteyse, karzdan talep edilen fazlalık da karz işlemini, "karz" olmaktan çıkarıp "riba"ya dönüştürmektedir. Bütün bunlardan hareketle genelde deyn özelde ise karzın riba ile yakından ilişkili ve işleme konu varlığın her ikisinde de aynı özellikleri haiz olduğu söylenebilir. Ancak mislî nitelikli bir varlığın aynı miktarda mislî ile geri alınmak üzere bir süreliğine başkasının mülkiyetine nakledilmesi işleminin karz, bunun farklı miktarlarda geri alınmak üzere yapılmasının ise riba olarak adlandırıldığı söylenebilir. Riba tarihin her döneminde bilinen ve uygulanan bir yöntem olduğundan Kur'an'da ve sünnette kastedilen riba da aynı şekilde tarihi süreçte bilinen ve uygulanan ribadır. Klasik kaynaklarda riba genelde "muamelede şart koşulan karşılıksız fazlalık" yahut "karşılıksız fazlalığın şart koşulduğu akit" şeklinde hukuki yaklaşımlarla tanımlanmıştır. Her iki tanımda da ribanın eylemsel yönüne değil hukuki bir bakış açısıyla hâsılat, fazlalık, sonuç tarafına vurgu yapılmıştır. Ribanın sadece fazlalığa odaklı hukuksal tarifi işin eylemsel tarafının gözlerden kaçması sonucunu doğurmuştur. Bunun bir neticesi olarak tarihte ve günümüzde çok sayıda işlemin özü itibariyle riba olmasına rağmen farklı ve masum ad ve kılıflarla uygulanması ve böylece insanlığın aldatılması durumu ortaya çıkmıştır. Ribanın etimolojik olarak doğru konumlandırılması, İslam'dan önceki dönemde nasıl kullanıldığı, hangi anlamlara geldiğinin bilinmesi, ayrıca İslam'ın bu kavrama yüklediği farklı anlam ve içeriklerin doğru anlaşılmasının konunun doğru zemine oturtulmasına katkı sağlayacağı kanaatindeyiz.

\section{Summary}

Riba (interest) remains up-to-date today as it was in the past, in terms of its economic nature and discussions about its legal (fiqhi) provision. In today's Turkish, the word interest is widely used instead of riba. In this text, we will sometimes use riba and sometimes interest to mean the same thing. Interest currently constitutes one of the important elements of both economic and financial life, and also is on the agenda of different branches of science in terms of its definition, content, types, effects on economic and social life, religious, legal and moral nature. Interestism is a behavior that is not seen as legitimate in Islam, as in pre-Islamic religion and thought systems, and is ordered to be avoided. We will also briefly examine the approach to the subject in the sacred texts of Judaism and Christianity. In this way, the meanings of riba in the Qur'an and the Sunnah, the points where riba combines and diverges with other asset transfer methods will be 
briefly discussed and some practices that we think are aimed at stretching / loosening the riba ban in our age will be criticized. Finally, based on the reasoning that the common definition of riba in the sources of fiqh does not fully meet riba, which is known and practiced throughout the history of humanity, and which is included in the Qur'an and the Sunnah, and this situation causes the negative consequences of current riba practices to be overlooked, an addition to the present definition, a different definition of riba will be proposed. Riba is explained in detail in the Qur'an and Sunnah, and the use of the word riba in the Qur'an and Sunnah contains important clues about the meaning of the term that can be attributed to it. In the Qur'an and Sunnah, riba is used in quite different patterns and meanings. Etymological examination of these uses is important in terms of understanding whether different meanings are attributed to the understanding of the word riba. Based on these uses, various riba theories have been developed in the historical process, and vast knowledge of riba has been created. In this study, we will especially focus on the definition of riba. However, in terms of laying the groundwork for the subject, we will touch on the views put forward on the way riba is handled in the Qur'an and the Sunnah, the variety of meanings attributed to it, its comparison with other commodity exchange methods, and the definition of riba in fiqh. In this context, the result that not only the name but also the verb, the economic transaction is meant by the word Riba, comes not only from the words mentioned above, but also from the examples in which riba is compared with some other economic behavior forms and methods of exchange of goods. However, since the focus is on the redundancy/noun, the operational meaning of the word is generally overlooked. The exchange of goods, on the other hand, can be legitimate and illegitimate in terms of its provision, and paid and free of charge in its nature/technical structure. In the verses where riba is mentioned, riba is presented in comparison with some of the methods of exchange of goods both free of charge and paid. From these comparisons, it is concluded that, in addition to the noun meaning of excess, riba is a unique, illegitimate method of exchange of goods with a price (action), which differs from other exchange methods with some of its features. We will briefly touch on the issue of sadaqa/zakat and qard, which are gratuitous among these property transfer methods, for comparison then we will compare bay' and riba, which is a onerous method of exchange of goods, and move on to the definition. We will also touch on the similarities and differences between riba and qard. In this context, the point where riba and qard differ is whether the person who gives them gains benefit or not. If qard is removed from its original purpose of legitimation and turned into a means of gain for the giver, the transaction ceases to be qard and turns into riba. Because in riba, like qard, the fungible and consumable goods are transferred to the property of someone else, the other party becomes the risk bearer, with expiration, similar of the goods that given at the beginning is demanded back -unlike qard- with a certain amount of excess. This situation, that is, demanding an excess in addition to the goods given in the qard, transforms the 
transaction from being qard to "riba". Just as when a fee is requested from the goods lent free of charge, the transaction does not remain as a "paid loan" but turns into "rent", and when the fungible goods left as depository to someone else are consumed, it ceases to be deposit and turns into qard, so the excess demanded from qard changes the transaction from qard to riba. Based on all these, it can be said that debt in general, qard in particular, is closely related to riba and has the same characteristics in both of the assets subject to the transaction. However, it can be said that the transfer of fungible goods to someone else's property for a while to be taken back in the same amount is called qard, and the transaction to be taken back in different amounts is called riba. Since riba is a method known and applied in every period of history, riba that is meant in the Qur'an and sunnah is riba that is known and practiced in the historical process. We do not consider the distinction of riba as Jahiliyya (riba of Qur'an) and sunnah (riba of fadl) appropriate. Because riba is expressed as a whole in different aspects in the scriptures. In classical sources, riba is generally defined with legal approaches as "unrequited surplus stipulated in the transaction" or "contract where unrequited surplus is stipulated". In both definitions, the emphasis is not on the operational aspect of riba, but on the revenue, surplus and result side from a legal point of view. This situation is similar in Western literature. The legal definition of riba, which focuses only on excess, has resulted in the fact that the operational side of the work is overlooked. As a result of this, many transactions in history and today, although they are riba in essence, are applied with different and innocent names and covers, thus deceiving humanity. We believe that the etymologically correct positioning of riba, how it was used in the pre-Islamic period, knowing what it means, and understanding the different meanings and contents that Islam ascribes to this concept will contribute to placing the subject on the right ground.

\section{Kur'an'da Riba Kavramı}

\subsection{Riba Kelimesinin Kur'an'daki Kullanımı}

Türkçedeki “faiz" kelimesinin Arapça karşılığı Riba (ربار)'dır. Riba (ربا) birinci babdan, illetli-nakıs, sonu "vav=و" " يَربُو "رِبا" "sökünden isimdir. Kelime "elif” ile yazılsa da genel kabule göre elif-i maksure "vav"dan bedeldir. Bu kökten kelimeler Kur'an'da farklı kalıplar halinde on iki surede, on beş ayette, on dokuz kez geçer. Kelime genelde üçlü (sülasi) kalıpta, geçişsiz (lazım), üç yerde dörtlü (sülasi mezid) kalıpta geçişli (müteaddî)dir. Sülasi mücerred birinci babdan iki kez mazî müfred müennes gâib kipinde "rabet=1, iki kez muzari müfred müzekker gâib kipinde "yerbû=يربو";

\footnotetext{
1 el-Hacc 22/5; Fussilet, 41/39.

2 er-Rûm 30/39.
} 


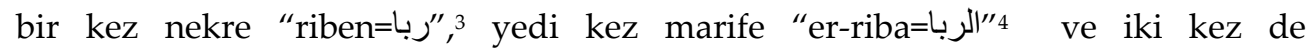
"rabvetin=eklinde toplam on kez camid isim olarak, biri müfred müzekker diğeri müfred müennes olmak üzere "rabiyen=6 رابيا ve rabiyeten=رابية7"7 şeklinde iki kez ismi fail, bir kez de "erba=8 şeklinde ismi tafdil kalıbında türemiş isim halindedir. Kelime sülasi mezid kalıplardan ise "ifa'l" ve "tefi'1" olmak üzere iki

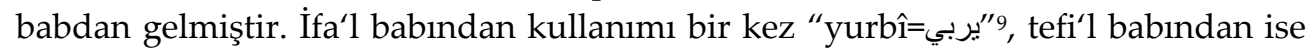
biri tesniye müzekker mazi gâib "rabbeyani=ريّيان" biri de muzari birincil şahıs

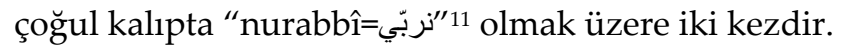

Riba (ربا) kök itibariyle sözlükte “artma, çoğalma, fazlalaşma (ziyade), büyüme, şişme, gelişme (nümuv), yükselme ('uluv, irtifa)" manalarına gelir'12. Fıkıhta riba için ıstılahî olarak farklı tarifler yapılmıştır. Kur'an'da riba kelimesi, yukarıda geçtiği üzere, mazî ve muzarî fiiller, camid ve müştak (türemiş) isimler halinde farklı kalıplarda geçmektedir. Ribanın tanımı yapılırken bu kullanımların dikkate alınmasının önemli olduğu kanaatindeyiz.

Fiil kalıbında sülasi mazi kipinde "ربت içine işleyen suyun etkisiyle toprağın kabarması, şişmesi; sülasi muzari kipinde "يَرَبر" bir malın, varlığın artması, çoğalması, " يُربي" bir varlığı arttırma, çoğaltma manasında; sülasi mezid mazi “ربّيَان" ve muzari "نربّي" kipinde ise çocuğu bakıp, besleyip büyütmek, geliştirmek anlamındadır. Türemiş (müştak) isim olarak biri eril ism-i fail "رابيا" sel suyu üzerinde biriken, yükselen/artan köpük, biri dişil ism-i fail "رابية" gittikçe artan güç, kuvvet; biri de ism-i tafdîl kalıbında "اربي" sayı veya mal bakımından bir başkasına göre daha fazla, daha üstün olma manasındadır. Camid isim olarak biri nekre "ربوة" tepe, yüksek yer; biri de nekre "رِبا" ve marife "13 şeklinde artık mal, fazla mal anlaminda gelmiştir.

İktisadi eylem anlamında ribadan bahsedilen ayetlerde kelime fiil olarak

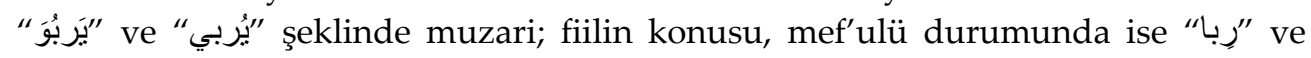
" şeklinde nekre ve marife isim olarak gelmiştir. Ancak genelde riba tariflerinde fiile yani eyleme değil, daha çok fiil sonucu ortaya çıkan isme odaklanılmış ve tarifler genelde isim merkezli yapılmıştır. Oysa kelime Kur'an'da

\footnotetext{
3 er-Rûm 30/39.

4 el-Bakara 2/275, 276, 278; Âl-i İmrân 3/130; en-Nisâ 4/161.

${ }^{5}$ el-Bakara 2/265; el-Mu'minûn 23/50.

${ }^{6}$ er-Ra'd 13/17.

7 el-Hâkka 69/10.

8 en-Nahl 16/92.

${ }^{9}$ el-Bakara 2/726.

10 el-İsrâ 17/24.

11 eş-Şuarâ 26/18.

12 Muhammed b. İbrahîm eş-Şîrâzî Fîrûzâbâdî, "rbv", el-Kâmûsu'l-muhît, 1/1659; İbnü'l-Manzûr, "rbv", Lisânu'l-arab, 14/305.

13 "nın camid'lik özelliğine ek olarak “ziyadeleştirmek” anlamında mastar isim olduğu görüşü de vardır ki ileride üzerinde ayrıntılı olarak durulacak.
} 
isim olarak kullanıldığı gibi bir eylemi ifade etmek üzere fiil olarak da kullanılmıştır. Ribanın fiil yönüne de odaklanılması durumunda farklı tariflerin yapılabilmesinin mümkün olacağı kanaatindeyiz. Nitekim marife şeklinde gelen “"الرباءn somut bir varlığın (fazlalığın) ismi olmasının yanında iktisadî nitelikli bir eylemin, faaliyetin, işlemin, varlık transfer yönteminin ismi; yani fiil kökünden türemiş mastar isim olduğuna dair görüşler de vardır. Hanefî fakihlerinden İbn Nüceym ${ }^{14}$ ve İbnü'l-Hümâm ${ }^{15}$ Bakara suresi 275. ayette alım satımla mukayese edilip haram kılındığ bildirilen "الربا"nın "mastar" kipinde "artırma, ziyadeleştirme

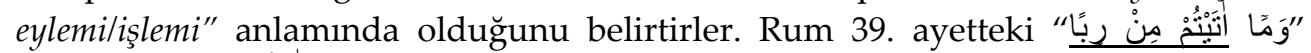

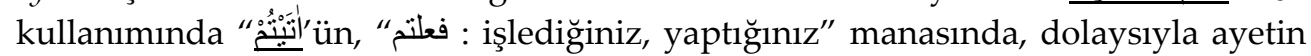
"riba özelliğine sahip eylemi, işlemi yaptığınız, işlediğiniz..." şeklinde anlaşılabileceğine dair görüşler mevcuttur ${ }^{16}$. Bu ayrıntıya girilmesinin sebebi, ribanın nesne odaklı yaklaşılıp sadece bir fazlalık, hâsılat olarak algılanmaması, aksine fazlalık yönüne ek olarak, fiil/eylem biçimi tarafının da dikkate alınarak bu fazlalığı doğurucu işlem, eylem biçimi olarak tanımlanmasının önemine dair kanaatimizdir.

Ribanın tepe, yükseklik, güç ve kuvvet bakımından üstünlük, fazlalık ve çocuğun beslenip büyütülmesi anlamlarındaki kullanımı konumuzla dolaylı olarak ilişkilidir. Makalemizin konusuyla doğrudan ilişkili olanlar ribanın iktisadi nitelikli fiil ve isimler halindeki kullanımıdır. Tefsir usûlünde yaygın kabul edilen nüzul

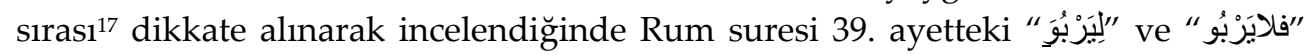
kelimeleri iktisadi içerikli şekilde fiil olarak, Al-i İmran suresi 130., Nisa suresi 161. ve Bakara suresi 275. ayetlerdeki " kelimeleri öncelikle isim olarak, Bakara suresi 275. ayetteki ikinci ve üçüncü “الرَّبَّبَ kelimeleri ise fiil ismi (mastar isim) şeklinde kullanıldığı görülür. Bu kullanım farklılıkları ribanın tanımı noktasındaki tartışmalara önemli ölçüde ışık tutucu mahiyettedir.

Riba kelimesi ile sadece ismin değil aynı zamanda fiilin, iktisadi eylemin de kastedildiği sonucu yalnızca yukarıda zikredilen kelimelerden çıkmaz, aynı zamanda ribanın diğer bir kısım iktisadi davranış biçimleri, mal mübadelesi yöntemleri ile mukayese edildiği örneklerden de anlaşılır. Ancak genelde fazlalığa/isme odaklanıldığından kelimenin eylemsel anlamı gözlerden kaçmaktadır. Mal mübadelesi ise hükmü açısından meşru ve gayri meşru, doğası/teknik yapısı itibariyle de bedelli ve bedelsiz olabilir. Ribanın geçtiği

\footnotetext{
${ }^{14}$ Zeynüddin Zeyn b. İbrâhim b. Muhammed Misri Hanefi İbni Nüceym, el-Bahrü'r-raik şerhu Kenzi'ddekâik (y.y., ts.), 4/210.

${ }^{15}$ Kemâleddin Muhammed b. Abdulvâhid İbnu'l-Hümâm, Şerhu Fethi'l-kadîr (Beyrut: Dâru'l-Fikr, ts.), 6/146-147.

${ }^{16}$ Muhammed Tahir b. Aşûr, Tefsîrü't-tahrîr ve't-tenvîr (Tunus: Daru Tunûsiyye, 1984), 21/107; Refik Yunus el-Mısrî, el-Cami fi usûli'r-riba (Dımaşk-Beyrut: 1991), 29; Abdulazim Celal Ebu Zeyd, Fikhu'r-riba (Beyrut: Müessesetür'r-Risale, 2004), 69.

${ }^{17}$ Muhammed Abdullah Diraz, er-Riba fí nazari'l-kânûni'l-İslamî (y.y., ts.), 10,11; el-Mısrî, el-Cami fi usûli'rriba, 27, 28.
} 
ayetlerde, riba hem bedelsiz hem de bedelli mal mübadele yöntemlerinden birkaçı ile mukayeseli şekilde ortaya konulmuştur. Bu mukayeselerden, ribanın fazlalık niteliğindeki isim anlamına ek olarak, bir kısım özellikleri ile diğer mübadele yöntemlerinden ayrılan, nev-i şahsına münhasır, gayri meşru nitelikli bir bedelli mal mübadele yöntemi (eylem) olduğu sonucu da çıkar. Bu mal transfer yöntemlerinden ivazsız nitelikli olan sadaka/zekât ve karz konusuna mukayese açısından kısaca temas edip daha sonra ivazlı mal mübadelesi yöntemi olan bey` ile ribayı karşılaştırıp tanıma geçeceğiz.

\subsection{Riba ile Sadaka/ Zekâtın Mukayesesi}

Ribayı yasaklayan ayetlerin önemli bir bölümü Bakara suresinde yer alır. Bu ayetlerden önce ise sadakanın önemi vurgulanıp teşvik edilir ${ }^{18}$. Sahip olunan maldan hak sahiplerine karşılık beklenmeksizin verilmesi anlamındaki sadaka, Bakara suresinin 276. ayeti ile Rûm suresinin 39. ayetinde riba ile irtibatlı şekilde geçer. Söz konusu ayetlerin ilkinde "ribaya verilen maldan elde edilen gelirin mahvedilip sadakaların bereketlendirileceğ $i$ " vurgulanır; diğerinde ise "insanların malları içerisinde artsın diye faize verilen malın Allah katında artmayacă̆ı, Allah'ın rızası gözetilerek verilen sadakanın ise kat kat artacağı" bildirilir. Ayetlerde sadaka ile ribanın benzer ve farklı yönlere sahip iki ayrı kavram ve uygulama olduğuna işaret vardır. İşlemin belli bir mal üzerinde yapılıyor olması ve malın mülkiyetinin bir taraftan diğerine aktarılması özelliği her iki işlemdeki benzer yöndür. Farklı olan ise, malın sadakada geri alınmamak (bedelsiz: kazanç amacı güdülmeyen), ribada ise fazlasıyla geri alınmak (bedelli: kazanç maksatlı olmak) üzere başkasına temlikidir. Burada ayetlerin metni ve siyak-sibakından ribaya konu olabilen malların sadaka ve zekâta da konu olacağı anlaşıldığı gibi sadaka vermek nasıl bir iktisadi eylem biçimi ise ribanın da aslında bir eylem biçimi olduğu sonucu çıkar.

\subsection{Riba ile Karzın Mukayesesi}

Riba ile irtibatlandırılan kavram ve dolaysıyla eylemlerden biri de karzdır. Ayetlerde riba ile genel anlamda "deyn" özel anlamda "karz" arasında ilişki kurulmuştur. İlgili ayetlerdeki "eğer tövbe ederseniz ana mallarınız sizindir"19, "eğer borçlu darlık (عسر) içinde ise ona süre tanıyın; eğer bunu sadaka sayarsanız sizin için daha hayırlıdır"20 ifadeleri karşılıklı borç-alacak ilişkisinden

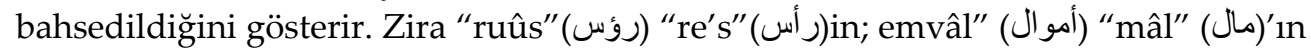
çoğulu olup tekili "re'sü'l-mâl” (رأس المال) dır. Re'sü'l-mal'ın Türkçe'deki karşılığ1

\footnotetext{
18 el-Bakara 2/261-274.

19 el-Bakara 2/279.

${ }^{20}$ el-Bakara 2/ 280.
} 
"sermaye"dir. Sermaye ise (karşılıklı iktisadi ilişkilerde) gelir elde etmek üzere bir iş ya da ortaklığa konan para ya da mala denir ${ }^{21}$. Kur'an'da ribadan bahsederken "ana mallarınız sizindir" 22 ifadesi sermayedâr ile karşı tarafın, bayi'-müşteri ilişkisi içerisinde değil, taraflardan birisinin sermayesini artırmaya yönelik bir teşebbüs, kredi ilişkisi içerisinde olduklarını gösterir. Kredi ise misli bir malı verip vadede aynısı ile geri alınması işlemine denir. Farklı miktarın talep edilmesi durumunda işlem kredi olmaktan çıkıp başka bir karaktere (ribaya) bürünür. Rûm 39. ayetteki "insanların malları içerisinde artsın diye ribaya verdiğiniz mallar Allah katında artmaz" ifadesi riba ilişkisinin bir bey"/alım-satım ilişkisi olmadığını gösterir. "Eğer borçlu darlık içinde ise..." ayetinde23 "el-'usr" (العسر) kavramı geçmektedir. "Usr", "'asera"(عر) fiilinin mastarı olup ismi fâili "mu'sîr"(معر) dir. Mu'sîr, bu kullanımda, borcunu ödemekte güçlük çeken kişiyi ifade etmektedir²4. Dolayısıyla ayetlerdeki "re'sü'l-mâl" ve "'usr" kavramları riba konusu malın karşı tarafın elinde alacak şeklinde bulunduğunu gösterir. Alacak ise karz/ödünç, alım-satım, tazminat, mehir veya hizmet sözleşmesi gibi borç doğuran sebeplerden biri ile meydana geldiği gibi bir de riba ile meydana gelir. Riba ile en çok karıştırılan kavram karzdır. Karz (القرض) sözlükte "kesmek, parçalamak, mislini geri almak üzere malı başkasına vermek, yol almak, bir yeri çaprazlama geçmek" anlamlarına gelir ${ }^{25}$. Terim olarak karz; "bir kimseye faydalanmak ve mislini iade etmek üzere bir malı verme" işlemine denir26. Bu kökten kelimeler Kur'an-1 Kerim'de farklı kalıplarda [isim, fiil (mazi, muzari, emir)] yedi ayette on üç kez geçer. ${ }^{27}$ Ancak karz fıkıhta yardımlaşma ve dayanışma maksatlı olarak verilenin sadece mislini geri almak üzere yapılan bir eylem olarak kurallaştırılmıştır. Başka bir ifade ile karz iyilik, yardımlaşma ve dayanışma amaçlı ivazsız/bedelsiz bir akittir. Bu nedenle Kur'an'ın birçok ayetinde karz, Allah'a borç verilmiş gibi tasvir edilip, tavsiye ve teşvik edilir ${ }^{28}$. Çünkü karz menfaat amacıyla değil yardımlaşma ve dayanışma saikiyle yapılan bir mal transfer işlemidir. Nitekim bir ayette "Fazlasını geri alma beklentisiyle başkasına ikram ve minnette bulunma! 29" denir. Karzı meşru kılınış amacından uzaklaştırıp kazanç amaçlı hale sokmak, bu amaçla gelire alet etmek, İslam'da da diğer dinlerde de meşru görülmemiştir. Riba ile karzın ayrıştığı nokta

\footnotetext{
${ }^{21}$ Mehmet Erdoğan, “sermaye”, Fikıh ve Hukuk Terimleri Sözlü̆̆̈̈ (İstanbul: 1998), 404; Büyük Larousse, "sermaye", 17/10372.

22 el-Bakara 2/279.

23 el-Bakara 2/280.

24 İbn Manzûr, "asr", Lisânu'l-arab, 4/564.

25 İbn Manzûr, "krz", Lisânu'l-arab, 7/217; es-Seyyid Muhammed Murteza Zebîdî, "krz", Tâcu'l-arûs (Misır: Matbaatü'l-Hayriyye), 1306/1888) 5/76; Fîrûzâbâdî, "krz" Kâmûsu'l-muhît, 1/1659; Hey'et, "krz" elMu'cemü'l-vecîz (Misr: 1980), 497.

${ }^{26}$ Buhûtî, Keşşâfu'l-kına'a, 2/298; Râğıb el-Isfahânî, "krz" el-Müfredât, 666; Nezih Hammad, Akdü'l-karz fi'ş-şerîâti'l-İslâmiyye (Beyrut: 1991), 198.

27 el-Bakara 2/245; el-Mâide 5/12; el-Kehf 18/17; el-Hadîd 57/11, 18; et-Teğâbun 64/17; el-Müzzemmil $73 / 20$.

28 el-Bakara 2/245; el-Mâide 5/12; el-Hadîd 57/18; el-Müzzemmil 73/20.

${ }^{29}$ el-Müddessir 74/6.
} 
veren kişinin menfaat elde edip etmemesidir. Karzın asıl meşru kılınış amacından çıkarılıp veren açısından kazanç aracı haline getirilmesi durumunda işlem karz olmaktan çıkıp ribaya dönüşür. Çünkü ribada da ancak karz gibi mislî ve tüketilir nitelikli mallar başkasının mülkiyetine geçirilmekte, risk karşı tarafa yüklenmekte, vade geldiğinde başta verilen malın bir benzeri ve -karzdan farklı olarak- belli oranda fazlası ile geri talep edilmektedir. İşte bu durum, yani karzda verilen mala ek olarak bir farkın talep edilmesi, işlemi karz olmaktan çıkarıp "riba" karakterine büründürmektedir. Nasıl ki bedelsiz olarak âriyet verilen maldan ücret talep edildiğinde işlem "ücretli ariyet" olarak kalmayıp "icare"ye dönüşmekte, bir başkasına vedia olarak bırakılan mislî mal tüketildiğinde akit vedia olmaktan çıkıp karza dönüşmekteyse, karzdan talep edilen fazlalık da karz işlemini, "karz" olmaktan çıkarıp "riba"ya dönüştürmektedir. Bütün bunlardan hareketle genelde deyn özelde ise karzın riba ile çok yakın ilişkisinin olduğu, işleme konu varlığın her ikisinde de ayn özellikleri haiz, ancak mislî nitelikli bir varlığın aynı miktarda mislî ile geri alınmak üzere bir süreliğine başkasının mülkiyetine nakledilmesi işleminin karz, bunun farklı miktarlarda geri alınmak üzere yapılmasının ise riba olarak adlandırıldığı söylenebilir.

\subsection{Riba ile Bey'in Mukayesesi}

“Bey”: "البيع”, “b-y-a: kökünden bir kelime olup sözlükte “bir şeyi başka bir şey ile değiştirmek, bir şeyi satmak veya satın almak, sözleşme yapmak, taahhütte bulunmak anlamlarına gelir." ${ }^{30}$ Bey' çok kapsamlı bir kelimedir. Her tür karşılıklı ilişkiyi içine alır. Allah ile kul arasındaki Tanrı-kul ilişkisi311 yönetici ve yönetilen arasındaki yöneten-yönetilen ilişkisi² ${ }^{32}$, sosyal ve ekonomik nitelikli her türlü ikili mübadele ilişkisis ${ }^{33}$ bey'in bu geniş çerçevesi içine girer. ${ }^{34}$

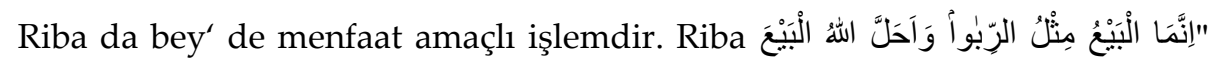
ş وَحَرَّمَ الرَبِوَّ"

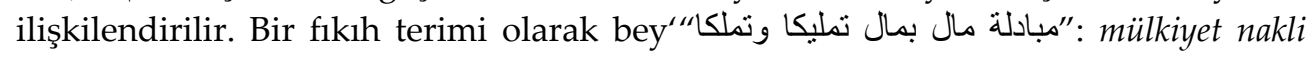
gerçekleşmek üzere bir malı başka mal ile değiştirmek" şeklinde ticari/kazanç amaçlı bir işlem olarak tanımlanır ${ }^{35}$. Bey'in tarifinde geçen her iki "مال" lafzı da nekre olduğundan, nahiv kuralı gereği, birbirinden farklı malları (muğayeret) ifade eder.

\footnotetext{
30 İbn Manzûr, "bya” Lisânu'l-arab, 8/23-26; Kâmusu'l-Muhît Tercümesi, 3/195; Şemsüddin b. Ahmed Şirbînî, Muğni'l-muhtâc ilâ ma'rifati meâni'l-Minhâc (Beyrut: ts.), 2/2.

31 Tevbe 9/111; Hac 22/40.

32 el-Fetih 48/10; el-Mümtehine 60/12.

33 el-Bakara 2/275, 282; en-Nûr 24/37; el-Cuma 62/9.

34 Ayrıntı için bk., Azeemuddin Subhanî, Divine Law of Riba: New Critical Theory (Kanada: Montreal, 2016), 40-41, 240-248.

${ }^{35}$ Kâsânî, Bedâyi, 7/197; İbni Abidîn, Haşiyetü İbni Abidin (Beyrut: Daru'l-Fikr, 1992), 4/501; el-Mevs1lî, elİhtiyâr li ta'lîli'l-Muhtâr, thk. eş-Şeyh Zuheyr Osman el-Cuayd (Daru'l-Erkam, ts), 1/ 231.
} 
$\mathrm{Bu}$ nedenle tarifin tercümesinde "başka mal” vurgusu yapılmıştır. Zira bey'de değişime konu şeyler asgari kalite düzeyinde de olsa farklıdır. Yoksa iyilik amaçlı ariyet ve karz işlemi hariç, bütünüyle aynı niteliklere sahip iki malın değişiminin pratikte bir anlamı olmaz. Az bir bedel karşılığında Yusuf'un satıldığ $1^{36}$, Ashab-1 kehf'ten birinin para verip karşılığında yiyecek aldığ $1^{37}$, insanların hidayeti verip sapıklığı satın aldığ ${ }^{38}$ ve Allah'ın, müminlerin can ve mallarını cennet karşılığında

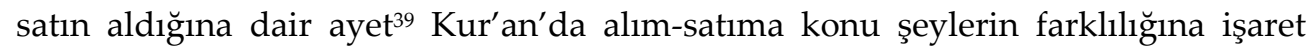
eden örneklerdir.

Nisa 29. ayette "mallarınızı bâtıl yollarla değil aranızda karşılıklı rızaya dayalı ticaretle yiyin/transfer edin" buyrulur. Bir işlemin ticaret kapsaminda değerlendirilebilmesi için farklı iki malın mübadele ediliyor olması gerekir. Zira kâr (ribh) farklı malların değişimi sonucunda ortaya çıkan farka denir. Kâr, sermaye yatırılarak satın alınan (yahut üretim gibi başka yollarla elde edilen) bir malın üçüncü bir kişiye tekrar satımı sonucunda, tahsil edilen bedelin başlangıçtaki sermaye ile karşılaştırılması sonucu belirlenir. Şayet ikinci işlem sonucunda elde edilen miktar, ilk işlemdeki sermayeden fazla ise kârdan, eşit ise başa baştan, az ise zarardan söz edilir. Bu da ancak farklı malların değişimi ile mümkün olur. Dolaysıyla ticaret üçlü bir işlem iken riba ikili işlemdir. Aynı malların birbirleri ile değişimi -bu işleme alım satım akdi dense dahi- gerçekte alış-veriş yahut "kâr" doğurucu ticarî işlem olmaz. Sonuç olarak bey` ve riba mal nakil yöntemi olmaları ve menfaat saikıyla yapılmaları bakımından birleşirler. Ayrıştıkları temel nokta, bey'in iki farklı malın değişimi ile ribanın ise sadece zimmette sabit olabilen misli ve (kalite açısından farklı olsa bile) aynı cins ve/veya aynı türden iki malın farklı miktarlarda değişimi ile gerçekleştiriliyor olmasıdır.

Alım satım insanlık tarihi boyunca toplumlar nezdinde meşru bir kazanç yöntemi olarak kabul edildiğinden olacak ki, bu dönemdeki faiz taraftarları beyi’i riba işlemine benzetmiş, bey'i müşebbeh ribayı müşebbehün bih şeklinde sunup riba yasağına "alış veriş işlemi de tıpkı faizli işlem gibidir" demek suretiyle itiraz etmişlerdir. Burada ilginç bir nokta vardır ki o da, müşriklerin bir mal mübadelesi eylemi olan bey'i riba ile mukayese ederken onu da bir mal transfer yöntemi olarak görmeleridir. Benzerlikteki ortak illet ise (vech-i şebeh) her iki işlemde değişime konu edilen mallar sonucu ortaya çıkan farktır (ribh ve riba). Bey'de ortaya çıkan fark kâr (ribh), bir eylem olarak icra edilen ribada ise ortaya çıkan fark gene fazla mal anlamında isim olarak "riba"dır. Kur'an-ı Kerim'de "alış verişin helâl, faizin haram kılındığg" ${ }^{\prime 40}$ bildirilirken bunların aslında birer mal mübadele eylemi oldukları reddedilmemiş, sadece faiz işlemi ile alış veriş işleminin fıtrî/teknik

\footnotetext{
36 Yûsuf 12/ 20.

37 el-Kehf 18/ 19.

38 el-Bakara 2/ 16, 175.

${ }^{39}$ et-Tevbe $9 / 111$.

40 el-Bakara 2/ 275.
} 
açıdan farklı mübadele işlemleri olduğu vurgulanmış; faizin, terim anlamıyla ticari amaçlı bey' kapsamında değerlendirilmemesi gerektiğine işaret edilmiştir ${ }^{41}$. Riba ve bey' arasındaki benzerlik ve farklılıkların dikkate alınması durumunda ribanın mahiyetinin daha sağlıklı şekilde tespit edilebileceği kanaatindeyiz.

\section{Sünnette Riba}

\subsection{Riba Kelimesinin Hadislerde Kullanımı}

Hadis kaynaklarında ribadan bahseden oldukça fazla rivayet mevcuttur. Bunlar incelendiğinde riba kelimesinin bazen terim anlamı dışında genel olarak haram mal, haksız kazanç anlamında, bazen de iktisadi eylem biçimi ve sonuçta غبن " المسترسل ربا: Alım satımda fiyatı belirleme yetkisini karşıdakine bırakana gabinde bulunanın yaptığ1 iş/aldığ1 mal ribadır." ${ }^{22}$; "الناجش أكل ربا خائن : Müşteri kızıştıran riba yiyici bir haindir."43 ve "إن اربي الربا عرض الرجل المسلم: Ribanın en fahişi Müslüman'ın haysiyeti ile oynamaktır."44 şeklindeki rivayetlerde riba terim anlamıyla değil de büyük günah ve klasik ribevi işlem dışında başka yollarla elde edilen haram kazanç anlamında kullanılmıştır.

Ribanın hadislerdeki bir diğer kullanımı terim anlamıyla ve fakat ribanın fıkhi hükmüne vurgu yapıcı nitelikli olanlardır. Bu anlamdaki hadislerden bir kaçı şöyledir: "Cahiliye faizi kaldırılmıştır.45; "Faiz; şirk, sihir, haksız yere adam öldürme, yetim malı yeme, savaştan kaçma ve namuslu kadına iftira etme gibi mahvedici yedi büyük günahtan biridir".46; "Faizi yiyene, yedirene, şâhitlik ve kâtiplik eden Allah'ın rahmetinden uzaklaşır." "77; "Faizcilikle zenginleşen kişinin sonu mutlaka fakirliktir." 48 Görüldüğü üzere bu rivayetlerde fikıhta mevzubahis olan riba terim anlamıla kullanılıp haramlığına vurgu yapılmaktadır.

Bir grup hadis ise ribanın mahiyeti hakkında bilgi verici ve ribayı eylem olarak tanımlayıcı nitelikli olanlardır. Bu çerçevedeki rivayetlerden bir kaçı şöyledir: "Dikkat ediniz! Cahiliye devrinden kalma faizin hepsi kaldırılmıştır. Sadece anaparayı alacaksınız. Böylece ne zulmetmiş ne de zulme uğramış olursunuz."49; "Peşin

\footnotetext{
${ }^{41}$ M. Hamdi Yazır Elmalılı, Hak Dini Kur'an Dili, nşr. İsmail Karaçam vd. (İstanbul: 1992), 2/245.

42 Beyhakî, Sünen, 5/349.

${ }^{43}$ İbni Hacer el Askalanî, Fethu'l-barî, nşr, M. Fuad Abulbaki (Beyrut: Darul-Fikr), "Kitabu'l-büyu': Babu'n-neceş", 4/35-356.

${ }^{44}$ Hakim en-Nisaburî, el-Müstedrek, nşr. Mustafa Abdulkadir Ata (Beyrut: Daru'l-Kütübi'l-İlmiyye, 1990), $2 / 37$.

${ }^{45}$ Müslim, "Hâc", 19; Ebû Dâvûd, "Büyu'", 50; Mâlik b. Enes, el-Muvatta', "Büyu'”, 83.

${ }^{46}$ Buhârî, "Vasâya", 2.

${ }^{47}$ Müslim, "Müsâkât", 105, 106.

48 İbn Mâce, "Ticâret", 58.

${ }^{49}$ Ebû Dâvud, “Büyu'”, 5.
} 
satışlarda faiz cereyan etmez."50; "Faiz ancak veresiyede olur."51; "Faiz yalnızca borçta olur."52; "Bir dînarı iki dînara, bir dirhemi iki dirheme, bir sa'ı iki sa'a değiştirmeyiniz. Çünkü faize girmenizden korkarım." "53; "Altınla altın, gümüşle gümüş, bŭğdayla buğday, arpayla arpa, hurmayla hurma ve tuzla tuz eşit ve peşin olarak değiştirilir. Ancak cinsleri farklı olursa peşin olmak şartıyla, istenildiğ $i$ gibi mübadele edilebilir." ;54 " Hurma hurmayla, buğday buğdayla, arpa arpayla, tuz tuzla, eşit miktarda ve peşin olarak mübadele edilir. Kim miktarı artırır yahut fazlalık isterse, faize girmiş olur. Ancak cinslerin değişmesi hali müstesnadır.55"; "Hayber savaşı esnasında, altın ve elmas karışımından yapılmış bir gerdanlı̆̆ın mübadelesi hakkında Hz. Peygamber, altının ilkönce gerdanlıktan ayrılmasını talep etmiş ve daha sonra "altın altınla eşit miktarda değiştirilsin" buyurmuştur. Başka bir nakle göre, Hayber savaşı sürecinde altın, gümüş ve bir kısım mücevherden yapılmış bir gerdanliğın ticareti ile ilgili soru soran bir sahabîye Fudâle (ö. 53/676) şöyle demiştir: "Altını al, bir kefeye koy ve onu tart, daha sonra diğerini aynı şekilde tart; altını sadece dengi karşılı̆̆ında al. Ben Hz. Peygamber'den "Allah'a ve ahirete inanan kişi altını sadece dengi karşılığında alsın" dediğinin duydum demiştir."56 Görüldüğü üzere bu gruptaki hemen tüm hadislerde riba faklı açllardan tanımlanmaktadır. Ama tümünde ortak nokta ribanın bir mübadele biçimi olduğuna işaret edilmesidir.

\subsection{Riba Kelimesinin Hadislerdeki Kullanımının Riba'nın Tanımı Açısından İncelenmesi}

Ribanın mahiyetine ilişkin hadislerden ribanın tanımı hakkında sonuçlar çıkarmak mümkündür. Hadislerde dikkat çekilen birinci nokta ribanın "peşin işlemlerde değil"57 "vadeli işlemlerden"58 ibaret borç sözleşmelerinde cereyan edeceğidir. Bu tür hadisler ribanın aynı nitelikli iki malın vadeli olarak ve fakat farklı miktarlarda değişiminden ibaret olan riba türünü ifade eder. Bu durum, ribanın hadislerde bey ${ }^{\prime}$ ve diğer bir kısım mübadele yöntemlerinden ayrı tutulduğunu gösterirken aynı zamanda ilgili rivayetlerin bu bakış açısıyla yorumlanıp riba tanımının bu doğrultuda yapılması gerekliliğine işaret eder. Ribanın mahiyetinden bahseden diğer hadis grubunda ise genel hatlarıyla borca konu olan mislî mallardan altısı (altın, gümüş, buğday, arpa, hurma ve tuz) zikredilerek bu tür malların birbirleri ile değişimi ile ilgili kurallardan bahsedilir.

\footnotetext{
${ }^{50}$ Müslim, “Müsâkât”, 103.

${ }^{51}$ Buhârî, "Büyu'", 79; Müslim "Müsâkât", 102, 104.

52 Dârimî, Sünen, thk. Favvâz Ahmed Zemrelî - Hâlid es-Sebı' el-Ilmî (Beyrut: 1407), “Büyu'”, 42.

${ }^{53}$ Ahmed b. Hanbel, Müsned (b.y.: Dâru'l-Fikr, ts.), 2/109.

${ }^{54}$ Müslim, "Müsâkât", 81.

${ }^{55}$ Müslim, "Müsakât", 83.

56 Ebu Cafer Ahmed Tahâvî, Şerhu Müşkilü'l-âsâr, nşr. Şuayb el Arnavud (b.y.: Müessesetü'r-Risâle, 1994), 4/243-244.

${ }^{57}$ Müslim, “Müsâkât”, 103.

${ }^{58}$ Buhârî, "Büyu'”, 79; Müslim “Müsâkât”, 102, 104.
} 
Altı mal hadisinde para niteliğindeki altın ve gümüşün ayrı, temel gıda maddesi niteliğine sahip olmakla birlikte tarihte aynı zamanda ödeme aracı olarak para yerine kullanılan buğday, arpa, hurma ve tuzun ise ayrı değerlendirildiği görülür. İlk iki malın (altın ve gümüş) diğer mallarla değişiminde ribaya düşme tehlikesi görülmediğinden işlem için peşinlik ve eşitlik şartı aranmamıştır. Altının altınla, gümüşün gümüşle değişiminde iki temel şart vardır; buna göre (1) işlemler peşin, (2) bedeller eşit olmalıdır. Altın ile gümüşün birbirleriyle değişiminde ise eşitlik şartı yoktur. Altı malla ilgili peşinlik şartının ilk bakışta karz-ı haseni de kapsadığı ve yasakladığı gibi bir durum ortaya çıkmaktadır. Ayet ve hadislerde karz-1 hasen teşvik edildiğine göre, peşinlik kuralı ile karz-ı hasenin yasaklanmasının söz konusu olmadığı sonucu çıkar. Altın ile gümüşün vadeli değişiminin yasaklanmasındaki maksadın, faiz farkının kura yansıtılıp işlemin faize alet edilmesinin önlenmesi olduğu söylenebilir. Altı malın kendi cinsleri arasındaki değişimlerinde peşinlik ve eşitlik şartının koşulmasında ise insanların iktisadî yararı olmayan bu tür bir işlemle uğraşmaktan menedilmesi ${ }^{59}$, takas ekonomisinden paralı ekonomiye geçişin temini ${ }^{60}$ ve faize götürebilecek hileli yahut değer belirleme zorluğu sebebiyle haksız kazanca götürücü yolların kapatılmasının hedeflenmiş olabileceği gibi gerekçeler ileri sürülmüştür ${ }^{61}$. İçindeki altın miktarı belirlenmeden gerdanlığın altın para karşılığı satılması ve kaliteli hurmanın kalitesiz hurma ile farklı miktarlardaki takasının faiz gerekçesiyle yasaklandığına dair rivayetlerde ise hem faize götürücü hileli yolların kapatılması hem de mübadele konusu malların kıymetinin adil şekilde belirlenememesinden kaynaklanacak haksız kazanç yollarının kapatılmasının hedeflendiği ileri sürülebilir. Nitekim ribanın anlamlarından biri de karşıllı̆̆ olmayan haksız kazançtır ${ }^{2}$.

Altı malla ilgili hadislerde esas itibariyle ayn nitelikli iki malın farklı miktarlarda vadeli olarak değişiminden ibaret işlemin yasaklandığ 1 anlaşılır. Bedellerde eşitlik ve peşinlik kuralının getirilmesinin, bu tür işlemlerin tümüyle faizli olduğunu belirtmek için değil, hukukun arkasından dolanılarak bu tür işlemlerin faizciliğe ve haksız kazanca alet edilebileceği endişesinden kaynaklandığ1 söylenebilir. Nitekim bir hadiste ${ }^{63}$ "faize düşmenizden korkuyorum" ifadesi yer alır. Buradan, aynı cins iki mislî malın farklı miktarlardaki her değişiminde faiz cereyan etmeyeceği, aksine değişimdeki maksadın önemli olduğu sonucu çıkar. Faize düşmenizden korkuyorum ifadesinde muhtemelen, ödünç verilebilir mislî malların mübadelesinin gelir amaçlı kredi işlemine alet edilebileceğine işaret vardır. Zira ödünç niteliğinde olmayıp krediden gelir hedeflenmediği için, mislî mallardan taze hurmanın tahmini ölçüyle kuru hurma ile

\footnotetext{
59 İbn Rüşd, Bidayetü'l-müctehid, 2/132.

${ }^{60}$ Beşir Gözübenli, “İslâm’da Faiz Yasağı ve Paralı Ekonomi”, 93-94.

${ }^{61}$ İbn Kayyim, I'lâmu'l-muvakkı̂n, 2/135; Abdulaziz Bayındır, Ticaret ve Faiz (İstanbul: 2012), 63-66.

${ }^{62}$ Kurtubî, el-Câmi' li ahkâmi'l-Kur'ân, 3/25-226.

${ }^{63}$ Ahmed b. Hanbel, el-Müsned, 2/109.
} 
değişiminden ibaret "ariyye işlemi" ${ }^{64}$ ne Hz. Peygamber'in cevaz verdiği rivayet edilir ${ }^{65}$. Ancak bütün riba sisteminin altı mal hadisi üzerine bina edilmesi ve bu altı mal hadisinin olması gerekenden farklı yorumlanması diğer ilgili ayet ve hadisleri işlevsiz kılma ve riba tanımının net olarak ortaya konulamaması tehlikesini barındırmaktadır. Altı mal hadisinin gerek zikri geçen mallar gerekse yasaklanan bazı işlem türleri açısından meseleyi vazedici esas delil değil, konuyu kapsamlı şekilde vazeden ayet ve hadislerde belirtilen hususlardan bir kısmını açıklayıcı örnek kabilinden anlaşılmasının daha isabetli olacağı kanaatindeyiz.

Hadislerden anlaşılan diğer bir husus, mislî malların vadeli değişiminden bahsedilen rivayetlerde her ne kadar bey' kelimesi kullanılsa da bu bey' ile hukuken "akit" anlamındaki bey’ değil, lüğat anlamıyla iktisadi olarak iki malın mübadelesi anlamındaki bey'in kastedildiğidir. Başka bir ifade ile, alım satım görüntüsüne büründürülmüş aynı nitelikli malların araya vade konularak farklı miktarlarda değişiminin bey olarak değil başka bir işlem, bu başka işlemin de riba işlemi olduğu murad edilmektedir. Çünkü alım-satım (bey ${ }^{\prime}$ ) işleminden söz edilebilmesi için farklı iki malın değişimi söz konusu olmalıdır. Bir kile buğdayın aynı özelliklere sahip bir buçuk kile buğday karşılığında altı aylığına satılması, karzı (ribayı) bey' olarak adlandırmaktan başka bir şey değildir66. Akidlerde ise itibar lafza değil maksadadır ${ }^{67}$. Bu durum bizi altı eşya ile ilgili hadislerin alım-satım değil, alım-satım görüntüsü altında yapılması muhtemel faizcilik çerçevesinde anlaşılması gerektiği sonucuna ulaştırır. Nitekim İbnü'l-Kayyim (ö. 751/1350)'de asıl haram kılınan ribanın cahiliye Arapları tarafından bilinen ve uygulanan açık riba (ribe'l-celî), altı mal hadislerinde yasaklanan ribanın ise, açık ribaya götürecek yolların kapatılması (sedd-i zerâyi) için yasaklanan kapalı riba (ribe'l-hafî) olduğu kanaatindedir68. "Riba ancak borçta olur"69 ve "riba ancak veresiyede olur"70 anlamındaki hadisler dikkate alındığında bir işlemde ribadan söz edebilmek için bir borç/riba ilişkisinin bulunması gerektiği anlaşılır. Borç ise ya karz ya da başka borç doğuran sebeplerle meydana gelir. Tarihteki muamele-i şeri'yye uygulamalarında olduğu gibi, alım-satım görüntüsüne büründürülmüş bir takım hileli işlemlerle de borç alış verişi yapılabilmektedir. Özetle, gerek Kur'an gerekse sünnette riba ayrıntılı şekilde açıklanmış, alım satım ve diğer bir kısım meşru mal mübadelesi yöntemlerinden farklılığı ortaya konulmuş ve tanımı konusunda

\footnotetext{
${ }^{64}$ A'râyâ satışı: Belli miktar kuru hurmanın tahminen aynı miktardaki taze hurmayla değiştirilmesi işlemine denir. (Halit Ünal, "Arâyâ", Tu rkiye Diyanet Vakfı Islâm Ansiklopedisi, 3/337)

${ }^{65}$ Buhârî, "Müsâkât", 17; Müslim, "Büyu'", 61-82; Ebû Dâvud, "Büyu'”, 20.

${ }^{66}$ Faizin alışveriş görüntüsü altında yapılmasına ilişkin ayrıntılı görüş ve örnekler için bk. Bayındır, Ticaret ve Faiz, 63-72.

${ }^{67}$ Mecelle, md., 3.

${ }^{6}$ İbn Kayyım, I'lâmu'l-muvakkûn, 2/135; Ebû İshâk İbrâhîm b. Mûsa b. Muhammed el-Gırnâtî Şâtıbî, elMuvâfakât fi usûli'ş-şerîati (Beyrut: Dâru'l-Ma'rife, y.y, t.y.), 4/42.

${ }^{69} \mathrm{Ahmed} \mathrm{b.} \mathrm{Hanbel,} \mathrm{Müsned,} \mathrm{5/209;} \mathrm{Ebû} \mathrm{Muhammed} \mathrm{Abdullah} \mathrm{b.} \mathrm{Abdirrahman} \mathrm{Dârimî,} \mathrm{Sünenü'd-Dârimî,}$ nşr. Mustafa Dib el-Boğa (Dımaşk: Dâru'l-Kalem, 1991/1412), “Büyû'”, 42.

${ }^{70}$ Buhârî, “Büyû'”, 79; Müslim “Müsâkât", 102, 104.
} 
önemli ipuçları verilmiştir. Buradan hareketle ribanın da aynen diğer mübadele yöntemlerinde olduğu gibi bir mübadele eylemi olarak da tanımlanmasının gerekliliği ortaya çıkmaktadır.

\section{Riba İçin Yeni Bir Tanım Teklifi}

Bey‘ en geniş anlamıla karşılıklı bir mübadele işlemi olduğundan, muhtemeldir $\mathrm{ki}$, bu sebeple riba fikıh literatüründe bey üst başlı̆gl altında ele alınmıştır. Ancak bey'in fıkıhta iktisadi yönüyle değil de hukuki açıdan terim anlamıyla ele alınıp işlenmesi bey' ile ribanın birbiri ile karıştırılmasına zemin oluşturmuştur. Buna ek olarak ayetlerde riba'nın sadaka, zekât ve bey' gibi hem bir mal nakil yöntemi hem de (karakter itibariyle farklı olsa da) "ribh"e benzer şekilde bir işlemden elde edilen fark, fazlalık şeklinde sunuluyor olması, konuyu daha da karmaşık hale getirmiştir. Riba yasaklandığı için, yukarıda bahsedilen karışıklığın da etkisiyle, bir kısım yasak unsurları barındıran bey' akdi riba olarak algılanmış, yasak unsurları barındıran bey'den elde edilen haksız kazanç da "riba" olarak değerlendirilmiştir. Oysa Yüce Allah ayette ${ }^{71}$ ribanın farklı, bey'in farklı birer iktisadi işlem olduğunu bildirir.

Ribanın mahiyetinin belirlenmesi ve dolaysıyla tanımının yapılması konusunda fıkıh kaynaklarında farklı yaklaşımlar söz konusudur. Hemen şunu ifade edelim ki, fikıhta riba bu ilmi disiplinin doğal bir sonucu olarak iktisadi açıdan değil, iktisadi eylem ve bunun sonucunda ortaya çıan fazlalı̆̆ın fıkhî/hukukî durumu açısından tanımlanmaya çalışılmıştır. Fazlalık açısından konuya yaklaşanlardan Malikî fakihi Adevî riba ilgili olarak şöyle der: "Sayılan veya tartllan mallardaki kesin yahut varsayılan (mevhum) fazlalık ve vadelerteleme riba türlerindedir"72. Hanbelî kaynaklarda ise riba "(mekilât ve mevzûnattan) özel bir takım şeylerdeki fazlalık" şeklinde tanımlanır ${ }^{73}$. Hanefî kaynaklarında yapılan tanımlardan bir kaçı ise şöyledir: "Riba alış veriş̧te şart koşulan karşıllksız fazlalıktır."74; "Bir bey" akdinde aynı cins malda şer'î ölçüler üzerinden şart koşulan karşılıksız fazlalıktır."75; "Mübadeleli akitlerde taraflardan birinin hakkı kabul edilen ve akit sırasında şart koşulan karşıllksız fazlalıktır."76 Her üç mezhepte de riba bir "fazlalık", yani "sonuç" şeklinde

\footnotetext{
${ }^{71}$ el-Bakara 2/275.

${ }^{72}$ Ali b. Ahmed el-Adevî es-Saîdî, Hâşiyetü'l-Adevî alâ Şerhi'l-Hıraşî̀ (Daru'l-Fikr, t.s.), 5/56.

${ }^{73}$ Muvaffakuddîn Ebû Muhammed İbni Kudame, el-Muğnî, nşr. Abdullah b. Abdulmuhsin et-Türkî Abdulfettâh Muhammed el-Hulv (Kahire: 1986), 4/3; Benzer tanımlar için bk., el-Behutî, Şerhu Müntehấliradât Dekâiku uli'n-nühâ li Şerhi'l-Müntehâ, thk. Abdullah Abdulmuhsin et-Türkî (Risale, yay., 2000), 3/245; el-Behutî, er-Ravzu'l-murbi Şerhu Zâdi'l-Müstakni, thk. Muhammed Ahmed et-Tayyâr vd. (Riyad: Dâru'l-Vatani, 2006), 205.

74 (هو الفضل الخالي عن العوض الششروط في البيع), Serahsî, el-Mebsût, 12/109.

${ }^{75}$ Semerkandî, Tuhfetü'l-fukahâ, 2/25; Kâsânî, 5/183.

${ }_{76}$ İbnu'l-Hümâm, Fethu'l-kadîr, 7/3.
} 
görülüp tanım ona göre yapılmıştır. Şafiî kaynaklarda ise riba daha çok sözleşme, yani akit tarafı ön plana çıkarılarak tanımlanır. Bir tanım şöyledir: "Riba, sözleşme esnasında şerî ölçüler açısından aynı miktarda (mümasil) olup olmadıkları bilinmeksizin özel bir bedel üzerine yahut bedellerden her ikisi veya birinin vadeli olması üzerine yapılan akittir"77. Hanefî âlimi Bedruddin el-Aynî, ribanın bey' gibi bir akit olduğunu, ancak bey'in sahih bunun (ribanın) fasit bir sözleşme olduğunu ifade ederken Şafiîler gibi ribanın akit, yani sözleşme tarafına vurgu yapar ${ }^{78}$. Bu tanımlardan ribanın mahiyetinin fukahaca nasıl tasavvur edildiğini net olarak çıkarmak oldukça güçtür. Çünkü kimisi işlem sonucu meydana gelen hâsılatı kimisi ise sözleşmeyi, yani akdi merkeze alarak tanım yapmışlardır.

Daha önce de ifade edildiği üzere fakihler arasında az da olsa işlemin iktisadi mahiyeti ve karakterini merkeze alıp riba tanımını bu minvalde yapmaya çalışanlar

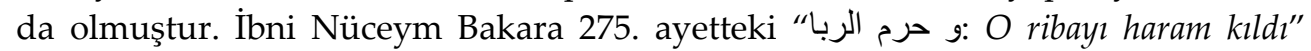
metninde geçen "riba"dan maksadın artırma fiilinin mastar1 "الزيادم: artırmak79"

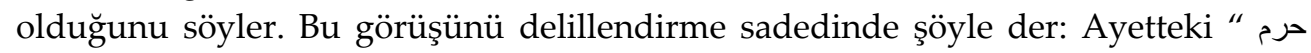

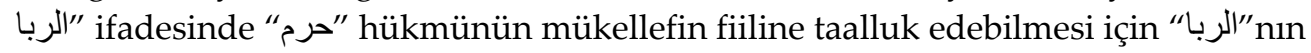
eylem ifade eden mastar manasında "artırma" yani bir eylem biçimi anlamına gelmesi gerekir80. İbnü'l-Hümam da konuyla ilgili şöyle der: Riba “الربا"kelimesi bazen bizzat "fazlalık"ın kendisi için, onu (fazlalığı) ifade eden isim anlamında kullanılır. Nitekim “تأكلو الربا" الأ Riba yemeyin!" mealindeki ayette "riba" bu anlamdadır. Bazen de fiil olarak mastar kalıbında "artırmak" manasında kullanılır. Ribanın haramlığından bahseden ayetin "حرم الربام" kismindaki "riba" bu anlamdadır. Yani karz ve selef (selem) işlemi, eylemi yoluyla mal artırımında bulunmayın demektir. Zira ayetteki haram hükmünün kulun fiiline taalluk etmesi için "riba"nın fiil, yani eylem olarak alınması gerekir81.

Aslında riba kavramı üzerindeki ihtilaflar Hz. Peygamber (s.a.v) öncesi döneme kadar uzanır. Bilindiği gibi Tevrat'ta faiz haram kılınmıştır ${ }^{82}$. Bir Yahudi başka biri ile faiz sözleşmesi yapamaz. Ancak bu kural esnetilmek istenmiş, faiz yasağı tümüyle Tevrat'tan silinemediğinden kavramın anlamı üzerinde oynanmış ve Tevrat'ta mutlak olarak faiz işleminin yasaklanmadığı aksine, Yahudilik dinine bağlı birinin dindaşı olan başka bir Yahudi'den borç olarak verdiği miktardan fazlasını alamayacağının kastedildiği şüphesi ortaya atılmıştır. Böylece Yahudiler, faizi kendi aralarında haram görürken, Yahudi olmayanlardan faizin alınabileceğini

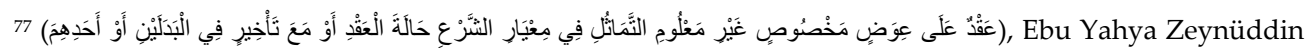
Zekeriyya b. Muhammed b. Ahmed Zekeriyyâ el-Ensârî, Esna'l-metâlib şerhu Ravzi't-tâlib, nşr. Muhammed Muhammed Tamir (Beyrut: Dârü'l-Kütübi'l-İlmiyye, 2001/1422), 7/471.

78 Ebû Muhammed Bedreddin Mahmûd b. Ahmed b. Musa Hanefi el-Aynî, el-Binaye fî şerhi'l-Hidaye (Beyrut: Dâru'l-Fikr, 1980/1400), 7/338.

"الزيادة"

${ }^{80}$ İbni Nüceym, Bahrü'r-raik, 6/210.

81 İbnü'l-Hümâm, Fethu'l-Kadîr, 6/146-147.

${ }^{82}$ Yeremya 15/10; Çıkış 22/ 25; Tesniye 23/19; Levililer 25/35-37.
} 
caiz kabul etmişlerdir.83 Günümüzde artık bu hassasiyet de terk edilmiş, Yahudi sermayeli finans kuruluşları din ve milliyetini sormaksızın her kişi ve kuruluşla faiz sözleşmesi yapar hale gelmişlerdir. Kur'an Yahudilerin bu yaklaşımını onaylamamış ve Yahudilerin cezalandırılma sebeplerinden biri olarak "Yasaklandikları halde faiz almaları" ve böylece insanların malların batıl yolla yemeleri olarak göstermiştir ${ }^{84}$.

Yahudi kaynaklarında faiz bir eylem olarak "Neshek=yılan sokması" şeklinde yorumlanır. Yılan sokması ilk anda çok hafif şekilde hissedilir. Fakat bu sokma neticesinde akıtılan zehir bütün vücudu kapladığında artık o kişi için kurtuluş imkânı kalmaz ${ }^{85}$. Görüldüğü üzere, Yahudi kültüründe faiz öldürücü etkisi bulunan yılan sokması şeklinde bir eylem türü olarak görülmektedir. Ancak uygulamaya gelince, bizzat faiz/riba eylemine, yani yılan gibi sokma eylemine değil, o eylem sonucu ortaya çıkan hâsılata odaklanıldığı, hâsılatın Yahudilerin lehlerine tahakkuku durumunda caiz, aleyhlerinde olduğunda yasak kabul edildiği anlaşılmaktadır. Oysa kendi kaynaklarındaki yorumlardan da anlaşıldığı üzere, esas olan sonuç değil, kim tarafından icra edilirse edilsin, o sonuca sebep olan davranış, eylem, yani yılan gibi karşı tarafı sokma işlemidir. Çünkü asıl olan zararı ortaya çıkaran eylemdir, sonuç ikincil derecede etkindir.

Faizin asıl karakterini perdeleyip onu makul ve meşru gösterme çabalarının diğer bir örneği Hıristiyan dünyasında ve Kilise uygulamasında görülür. İncil'de "Birilerine ondan bir karşıllk ummak için ödünç verirseniz, bunun için hangi teşekkür beklenir? Günahkârlar da bir şey almak için birbirlerine ödünç verirler" 86 denilerek fazlasını almak üzere bir iktisadi değerin başkasına verilmesi eyleminin yanlışlığına ve tasvib edilmediğine vurgu yapılır. Burada aslında Ahd-i kadimdeki (Tevrat) faiz yasağ1 tekrarlanmış, teyit ve tasdik edilmiş olmaktadır. Bu kural Hıristiyan dünyasında uzun süre geçerli kabul edilmiş, faizli işlemler/sözleşmeler Kilise kanunları ile yasaklanmıştır. Ancak XVI. yüzyılda faizi meşrulaştırma çabaları yoğunlaşmış, Kutsal kitaptaki yasaktan maksadın aşırı faiz alınarak insanların sömürülmesinin engellenmesi olduğu şeklinde bir gerekçe icat edilmiştir. Daha sonraları, Yahudilerde olduğu gibi, yasağın eylem yönü göz ardı edilerek sonuca odaklanılmış ve usury (paranın kullanımı karşıllğı ödenen fiyat) ve interest (paradan mahrum kalınan süre karşllığında hak edilen gelir) ayrımına gidilerek yasak gevşetilmiş̧ ${ }^{87}$ ve nihayet 1918 yılında Kilise tarafından yayımlanan bir genelge ile beşeri hukukun izin verdiği hakkı gözeten dengeli orandaki faizin

\footnotetext{
${ }^{83}$ Tesniye $23 / 20$.

${ }^{84}$ en-Nisâ 4/161.

${ }^{85}$ Rov Yithsak Haleva vd. (ed.), Türkçe Çeviri ve Açıklamalarıla TORA ve AFTARA: ŞEMOT, çev. Moşe Farsi (İstanbul: 2004), II/275; III/588-589.

${ }^{86}$ Luka 6/34.

${ }^{87}$ Tarık el-Diwani, Faiz Sorunu, çev. Mehmet Saraç (İstanbul: İz Yayıncllık, 2011), 44-46.
} 
meşruiyeti resmen kabul edilmiştir. ${ }^{88}$ Görüldüğü üzere, Hıristiyanlıkta da işlemin fıtratı göz ardı edilerek dikkatler bizzat eyleme, yani faiz uygulamasının (negatif nitelikli) iktisadi karakterine değil, kavram tartışmasına yönlendirilmiş ve böylece faizciliğin önü açılmıştır.

Batı dünyasındaki bu tür yaklaşımlara sadece dini temelli metinlerde değil faiz konusunu inceleyen iktisadi metinlerde de rastlanır. Kapitalist anlayışla yazılmış eserlerin hemen tümünde faiz sermayedarın " $X$ " türünden bir ekonomik tutumunun sonucu, karşılığı, mükâfatı olarak görülüp farklı gerekçelerle aklileştirme, masumlaştırma çabasında olunmuştur. Fakat bu kapitalist literatürün hemen tümünde faizin iktisadi eylem niteliğine değil sonuç, hâsılat, fark şeklindeki özelliğine, niteliğine odaklanılmıştır. John Babtist Say "sermayenin üretime katılma payı" olarak gördüğü faizi emeğin karşılığında alınan ücret, dayanıklı malın menfaatinin kullandırılması karşılığı talep edilen kira yahut toprağın kullandırılması karşılığı talep edilen ranta benzetmiştir89. Adam Simith ve David Ricardo gibi iktisatçılar faizi “ödünç alanın bu paradan sağlayacağı kâr, kazanç için ödünç verene takdim etmesi gereken karşılık" olarak değerlendirmişler. J. Maynard Keynes ve Alfred Marshall ise faizi "tasarrufun/paradan tatminden vazgeçmenin/beklemenin mükâfatı" olarak kabul ederler ki buna likidite tercihi denir ${ }^{90}$. Faizi makulleştirme sürecinde ileri sürülen görüşlerden biri de "sermayenin üretkenliği" teorisidir. Bu yaklaşım Sermayenin Prodüktivitesi Teorisi olarak adlandırılır. Buna göre sermaye emek gibidir. Faiz ise kredi olarak alınan sermayede oluşan değer artışının karşılığıdır. Dolaysıyla faizin ödenmesinin sebebi sermayedeki üretkenlik özelliğidir ${ }^{91}$. Sonuç olarak, faizi haklı çıkarmak üzere geliştirilmiş batı kaynaklı teoriler, faiz olgusunu birinci olarak verimlilik teorisine dayandırırlar. Buna göre, borç alınan sermaye verimli amaçlar için kullanıldığı için borç veren taraf faiz almayı hak eder. İkincisi tasarruf sahibinin ödüllendirilmesi gerektiği yaklaşımıdır. Bunlara göre, tasarruf fedakârlığı faiz şeklinde bir karşılıkla ödüllendirilmelidir. Sonuncusu likit değer argümanıdır ki buna göre, faiz likiditeden vazgeçmenin karşılı̆̆ 1 olarak ödenir ${ }^{92}$.

Batı kaynaklı argümanlara dikkat edildiğinde faizin son derece makul ve masum ve hatta iktisadi hayat için gerekli bir enstrüman şeklinde sunulduğu görülür. Çünkü bahsedilen iktisadi tutum ve davranışların ilkesel olarak eleştirilebilecek bir tarafı yoktur. Bir kişinin harcamalarından kısarak tasarrufta bulunması, tasarrufunu başkasına vermek suretiyle fedakârlık yapması,

\footnotetext{
${ }^{88}$ Abdullah Mesud Küçükkalay, İktisadi Düşüncede Faiz: Antik Yunan'dan Monetarizme (İstanbul: Çizgi Kitabevi, 2018), 159.

89 İsmail Özsoy, İslam İktisadında Faiz ve Ortaya Çıkan Problemler (İstanbul: İstanbul Üniversitesi, Sosyal Bilimler Enstitüsü, 1991), 29.

90 Özsoy, İslam İktisadında Faiz ve Ortaya Çıkan Problemler, 30.

${ }^{91}$ Özsoy, İslam İktisadında Faiz ve Ortaya Çıkan Problemler, 32.

92 İsmail Zeyrek- Zekeriya Mizırak, "Faiz Teorileri Üzerine Bir İnceleme: Finansal İstikrarsızlık Hipotezinin Temel Dayanağ1", Selçuk Üniversitesi S.B.E. Dergisi 22 (2009), 386.
} 
sermayenin üretken projelerde kullanılmak üzere verimli alanlara kanalize edilmesi gerek iktisadî gerekse ahlakî açıdan son derece makul davranışlardır. Fakat üzerinde durulması gereken husus, sayılan bütün bu makul davranışların faiz denen o farkı talep etmeyi haklı kılıp kılmadığıdır. Başka bir ifade ile faiz, sermaye tasarruf edilip verimli alanlarda kullandırıldığ taraflar kendi aralarında iktisadi ve hukuki ilişkilerden özel bir türüne başvurdukları için mi talep edilmektedir? Bu meseleye açılık kazandırılması konumuz açısından önem arz etmektedir. Yani kişi harcamalarından fedakârlık yapıp sürekli tasarrufta bulunsa yahut sermayesini çok verimli alanlarda bizzat kendisi ya da başkasıyla ticaret temelinde ortaklıklar kurarak çalıştırıp bolca kazanç sağlasa buna faiz denir mi? Hayır denmez. Oysa yukarıda ileri sürülen argümanların tümü bu tür kişi ve eylemler için de söz konusudur. Şurası açıktır ki fazlalık şeklindeki faiz gerçekte, sermayedarın başkası ile girdiği bir mübadele/borç ilişkisi sonucunda talep edilmektedir. Dolayısıyla bu argümanlarla dikkatler başka alana yönlendirilmekte, faizi doğuran esas eylem olan karzın/kredinin kazanç maksatlı kullanımı gözlerden kaçırılmaktadır. Oysa kişi hangi saikle sermayeyi biriktirirse biriktirsin, onu hangi alanda değerlendirirse değerlendirsin, sermayesi kazansın veya kaybetsin bütün bunlar ikinci planda kalmakta, gerçekte hukuken ve iktisaden girişilen borç sözleşmesi neticesinde, borç verenle borç alan bir tür iktisadi ilişki kurmakta, borçlu alacaklıya belli meblağı ödeme yükümlülüğü altına girmektedir. İzaha muhtaç olan nokta şudur: İnsanlığın yardımlaşma ve dayanışma amacıyla icat ettiği ve dinlerin bu karakteristik yapısını dikkate alarak meşru görüp teşvik ettiği "borç/karz" diye adlandırılan bir iktisadi ve hukuki eylem, işlem biçimi kazanç aracı haline dönüştürülebilir mi, dönüştürülürse insanlığın hayrına $\mathrm{m} ı$ yoksa zararına mı sonuç doğurur? Kısacası mesele Doğuda da Batıda da aynı mantık zemininde yorumlanmış ve mevcut yaklaşım problemi içinden çıkılmaz hale büründürmüştür.

Oysa daha önce de ifade edildiği üzere faizle ilgili ilk nazil olan Rum suresinin 39. ayetinde malı ribaya (faize) vermekle zekâta vermekten ibaret iki iktisadi eylem biçimi arasında mukayese yapılır ve zekât verme eylemi tavsiye edilir. Ayetin cümle yapısından zekât eylemi ile faizcilik eyleminin iki farklı davranış, iki farklı iktisadi eylem türü olduğuna işaret vardır; riba eylemi, gerçek anlamda katma değer üretici değilken zekât (sadaka) varlığı kat kat artırıcıdır. Buradan Kur'an'da kullanılan "riba" kelimesi ile -zekât verme örneğinde olduğu gibi- öncelikle bir eylemin, davranışın, varlık aktarma yönteminin murat edildiği anlaşılır. Faiz yasağı konusundaki kesin hükmün bildirildiği Bakara suresi 275. ayette ise riba ile alım satım iki kez karşılaştırılır. Birincisinde faizcilerin itirazlarına atıfla "...alım satım işlemi tıpkı riba işlemi gibidir"93 dedikleri bildirilir. İtirazcıların algılamasında ribanın aynen alım satım işlemi gibi bir varlık transfer 
yöntemi/eylemi olarak görüldüğü sonucu çıkmaktadır ki -vardıkları hüküm bir tarafa- özü itibariyle bu yaklaşım tarzı aslında ayetteki bir sonra gelen ifade ile onaylanır. Zira ayetin cevap mahiyetindeki ikinci kısmında "Allah, alım-satımı helâl faiz işlemini haram kılmıştır"94 buyrulurken benzer bir üslup söz konusudur. Ayetin devamındaki "Kime, Rabbinden bir uyarı gelir de ona son verirse, geçmişte olan kendinindir, onun işi Allah'a aittir. Kim de ona dönerse işte onlar cehennemliktir" bölümündeki iki adet " $o$ "na ifadesi, zamirin en yakına gideceği kuralı gereği, faizin eylemsel niteliğine işaret etmektedir. Dolayısıyla gerek Kur'an'ın gerekse itirazcıların dilinde alış veriş gibi ribanın da bir eylem olarak kabul edildiği ve bu anlamda kullanıldı̆̆ görülmektedir.

Ancak şu hususu göz ardı etmemek gerekir ki, riba ayetlerde yalnızca bir eylem türü olarak değil aynı zamanda bir hâsılat, fazlalık anlamında da kullanılmıştır. Bakara suresi 275. ayetteki "riba yiyenler"95, Al-i İmran suresi 130. ayetteki "ribayı yemeyin" 96 ve Nisa suresi 161. ayetteki "ribayı almaları yüzünden"97 terkiplerinde geçen "riba" kelimelerinin bir eylemi değil o işlemden doğan hâsılatı ifade ettikleri açıktır. Dolaysıyla Arap dilinde ribanın (çok/eş anlamlı) müşterek bir kelime olduğu, Kur'an'da hem bir varlık mübadelesi eylemini hem de bu eylemden oluşan hâsılatı/farkı içerir mahiyette kullanıldı̆̆ı anlaşılmaktadır.

Allah'ın Elçisi'nin kullanımlarında da benzer durum söz konusudur. Allah'ın

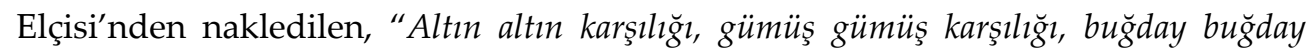
karşılığı, arpa arpa karşılı̆̆l, hurma hurma karşılı̆̆ peşin olarak değiştirilir. Kim fazla verir ya da fazlalık isterse ribâya düşmüş olur, o ribâyı alan ile veren aynıdır"98 mealindeki rivayette "riba" öncelikle bir eylem türü; mübadeleye konu malların (vadeli olarak) farklı miktarlarda değiştirilmesi işleminin adı, ikinci olarak da fark/hâsılat anlamındadır. Çünkü hadiste, riba cereyan eden malların birbirine denk ve peşin şekilde değiştirilmesi işlem ve yöntemi faiz olarak değil meşru yöntem (karz-1 hasen, bey') olarak gösterilmekte, miktarlarda farklılık olduğunda faize girilmiş, faizcilik yapılmış olunacağı beyan edilmiştir. Dolaysıyla vurgu öncelikle mal mübadelesi işleminedir; o işlemden doğan fark ikincil derecededir. Allah'ın Elçisi'nden nakledilen "Borç verene menfaat sağlayan her karz işlemi/sözleşmesi (karz değil) ribadır." 99 anlamındaki rivayet 100 ile "Faiz ancak vadeli işlemde söz konusu olur" anlamındaki rivayetlerde101 de riba ile bir eylemin kastedildiği görülür. Riba ile ilgili olarak nakledilen "O ribayı yiyeni,

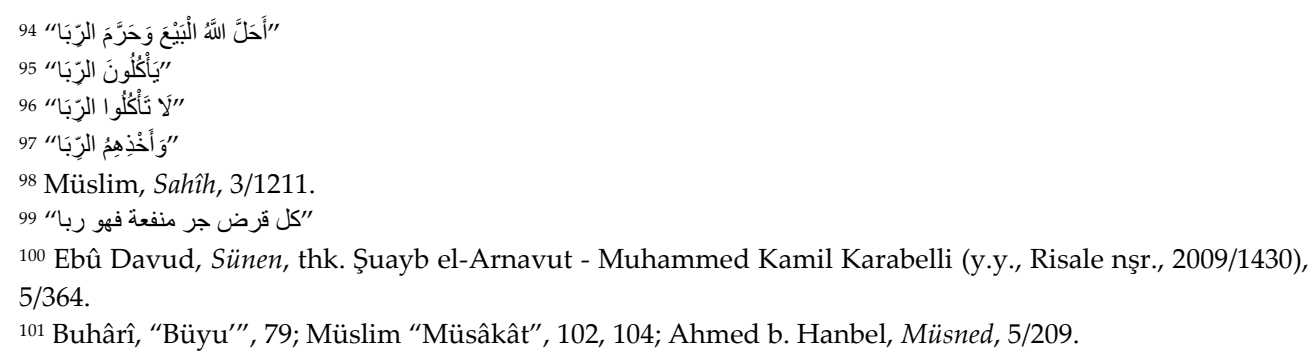


yedireni... lanetledi"102 ve Veda hutbesinde irad edilen "Biliniz ki Câhiliye ribâstnın tamamı kaldırılmıştır, anaparalarınız sizlerindir"103 şeklindeki rivayetlerde ise "riba" öncelikle bir hasılat, fark anlamındadır.

Sonuç olarak riba tanımında bu ayrıntının göz önünde tutulmasının önem arz ettiği kanaatindeyiz. Hatta konuyla ilgili olarak, sebep niteliğindeki işlem olmadıkça bu işlem türünün bir sonucu niteliğindeki hâsılatın da varlığından söz edilemeyeceğinden, bu hususta asıl olanın hasılat olmamasından hareketle, bu sonuca değil de ona ulaştıran eyleme odaklanılmasın gerekliliği göz ard1 edilemeyecek bir gerçektir. Nitekim hırsızlık, kumar ve rüşvet gibi gayri meşru işlemlerde vurgu bu yollarla elde edilen varlığa, "kazanç"a değil de buna temel teşkil eden eyleme olduğu ve fikıhta da bu yasakların hasılat değil eylemsel yönleri esas alınarak tanımlandığı dikkate alındığında ribada da benzer bir yaklaşımın takibinin gerekliliği ortaya çıkar. Ancak hem klasik hem de konuyla ilgili modern kaynaklarda bu noktanın pek ön plana çıkarılmadığı, hâsılata, sonuca odaklı bir edebiyatın baskın olduğu gözlemlenmektedir. Bu durum da hem tarihte hem de günümüz faiz tartışmalarında büyük karışıklıklara yol ve zemin oluşturmuştur.

Tarihte bey'ul-îne, bey'ul-vefâ, bey'ul-istiğlâl, muamele-i şeriyye gibi özü itibariyle katma değer üretici nitelikli iktisadi bir eylem olmayan, aynı nitelikteki iki malın farklı miktarlarda değişiminden ibaret olan hileli işlemlere bazılarınca cevaz verilmiştir. Bunun benzerine günümüz finans piyasalarında da şahit olunmaktadır. Finansal piyasalardaki birçok faizli işlem, insanların gözlerinden saklanırcasına, masum hale büründürülüp farklı kavramlarla ifade edilmektedir. Örneğin, her biri gerçekte karzın/borcun faize dönüştürülmüş halinden ibaret olan birçok işlem "Bono" yahut "Tahvil Alım-Satımı", "Bono" veya "Tahvil İhracı", hazine veya merkez bankalarının "Varlık Alım-Satımı", "Geri Alma Şartlı Satım” (Repo), "Sat, Kirala-Geri Satın Al" (Sale, Lease and Buy-back), "Altına Dayalı Kira Sertifikası", Teverruka Dayalı Kira Sertifikası", "Yönetim Sözleşmesi Temelli Kira Sertifikası" "Emtia Murabahası", "Teverruk", "Gelire Endeksli Senet", "Anapara ve getiri garantili vekâlet yatırımı (Wakala investment)", "Çifte vekâletle bankacılık murabahası" gibi ilk bakışta helal nitelikli normal ticari işlemi çağrıştıııcı kavramlarla ifade edilmektedir. İkincil piyasalarda senet kırdırma yoluyla faizli borç sözleşmesinden ibaret olan çok sayıdaki finansal işlem son derece doğal gösterilerek, "Faktöring işlemleri”, "İpotekli menkul kıymet alımı- satımı”, "Varlığa endeksli menkul kıymet ihracı" vb. şekilde isimlendirilmektedir. Kısacası, günümüzde finansın dili oldukça tahrib edilmiştir. Mekke dönemi müşriklerinin faizli işlemi insanlığın meşru kabul ettiği alım satım kapsamında gösterip zihinleri bulandırma çabaları sadece o dönemde kalmamış, gerek Müslüman gerekse gayri Müslim uzmanlar(!) tarafından günümüzde de bütün yoğunluğuyla

102 “" لعن آكل الرباوموكله " Ebû Dâvud et-Tayâlisî, Müsned, 45.

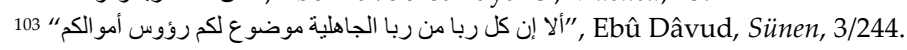


sürdürülmektedir. Örneğin 1911 yılında faizli Mısır Milli Bankası'nın kuruluş müzakerelerinde Kur'an'daki faiz (riba) yasağı ile aslında fahiş tefecilik faizinin kastedildiği, normal orandaki faizin yasaklanmadığı görüşünden hareketle faizli bankanın fıkhi temellendirilmesi(!) yapılmaya çalışılmış, Osmanlı'daki para vakıflarının hileli işlemlerine ilişkin fetvalar faizli bankaya delil gösterilmiştir ${ }^{104}$. Bu düşünce dillendirilmeye devam etmiş, 31 Ekim 2002 tarihinde dönemin Mısır Baş Müftüsü M. Tantâvî'nin başkanlığında yapılan toplantıda Mısır İslâm Araştırmaları Kurulu (Mısır Din İşleri Yüksek Kurulu) banka faizinin helâl olduğuna ilişkin fetva yayınlamıştır105. Benzer görüşlere son yıllarda bazı akademisyenlerin açıklamalarında da rastlanılmaktadır. Sonuçta, Allah bir eylemi yasaklamışken, insanların dikkati eyleme değil, onunla ilintili detay konulara yönlendirilmiş, kelime oyunları ile toplumların zihinleri meşgul edilerek bu sayede faiz yoluyla sömürü asırlardan beri devam ettirilmiştir.

Nisa 29. ayette mal transferinin iki ana yönteminden bahsedilir; bunlardan birincisi karşılıklı rıza temelli ticaret yöntemi, diğeri batıl mal transfer yöntemlerdir. Meşru görülen kazanç amaçlı varlık transfer yöntemi sadece bütün alt çeşitleri ile ticarettir. Dolaysıyla faizin bunlardan hangisinin kapsamına girdiğinin tespit edilip tanımın buna göre yapılması önem arz etmektedir. Ticaret daha önce de belirtildiği üzere farklı nitelikli mal ve hizmetlerin değişim işlemidir. Dolaysıyla bir işlemin ticaret olarak adlandırılması için ortada değişime konu edilen iki farklı malın veya hizmetin var olması ve bunların taraflardan birinden diğerine ebedi şekilde naklinin gerçekleşiyor olması gerekir. Mal yahut hizmet nakline dayanmayan, birine verilen şeyin (vasıf itibariyle) aynısıyla yahut daha fazlasıyla geri alınması işlemi hiçbir medeniyette ticaret olarak adlandırılmaz. İnsanlık ticareti ticaret, faizli işlemi de riba/faiz olarak adlandırmıştır. Mal transfer yöntemlerinden her birinin iktisadî, hukukî, kaydî ve ahlakî yapı ve işlevi farklıdır. İki farklı malın birbirleri ile değiştirilmesi alım satım (bey`), malın karşılıksız olarak başkasına verilmesi en geniş anlamıyla sadaka, kendisi tüketilmeksizin menfaatinden yararlanılan bir malın belli bir süre ile kullandırılıp geri alınmak üzere başkasına verilmesi, işlem ücretli ise icâre, ücretsiz ise âriyet, kendisinden ancak tüketilmek suretiyle yararlanılabilen mislî bir malın belli vade sonunda aynı miktarla misli ile geri alınmak üzere verilmesi karz-1 hasen, ek bir meblağla geri alınmak üzere verilmesi ise (bir mal transfer yöntemi olarak) faiz işlemi/riba olarak adlandırılır. Mislî ve

\footnotetext{
104 Bkz. İsa Abduh, Bünûk bila fevâyid (Mısır: Daru'l-í'tisâm, 1977), 110-113.

$105 \mathrm{Bu}$, hey'et olarak banka faizinin caiz olduğuna dair verilmiş ilk ve (31 Aralık 2003 tarihi itibariyla) nihai fetvadır. Hey'et faizli bankacılıkta uygulanan faizinin cevazına ilişkin görüşünü şöyle gerekçelendirir:

(1) Banka tarafından verilen faiz banka ile müşteri arasındaki vekâlet ilişkisine dayanır. Müşteri bankayı vekil tayin etmiş, banka da bu vekâlete dayalı olarak, vekil sıfatıyla parayı çalıştırır.

(2) Devlet ve onun vatandaşı arasında faiz sözkonusu olmaz. (Konuya ilişkin ayrıntılı bilgi için bk., elAzîzî, Muhammed Râmiz Abdulfettâh, Beyânu'l-hukmi'ş-şeri'yyi fi'l-fevâidi'l-masrifiyyeti redden alâ fetvâ mecmai'l-buhûsi'l-İslâmiyye (Amman: 2003); Yusuf el-Kardâvî, "Fevâidü'l-bunûk”, wwww.islamnafatwa.com.
} 
tüketilen bir malın belli vade ile kullandırılmasından (riba işleminden) elde edilen gelire de aynı şekilde faiz (riba) denir.

Bütün bunlardan hareketle kanaatimizce ribanın hem hukuki hem de iktisadi olmak üzere temelde iki açıdan tanımının yapılması gerekir. Hukuki açıdan "akit" yönü, iktisadi açıdan ise "mübadele yöntemi" ve bu yöntemden ortaya çıkan "hasılat" yönü dikkate alınmalıdır. Çünkü Kur'an'daki faizle ilgili ayetler bizi buna

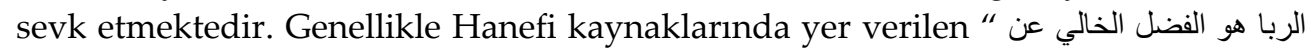
العوض المشروط في البيع: Riba alış verişte şart koşulan karşıllısız fazlalıktır"106 şseklindeki tanım hem sonuç odaklı hem de ıstılahî (hukuki) anlamıyla bey‘ temellidir. Diğer tanımlar da benzer niteliktedir. Bu tanımlar yalnızca hâsılat şeklindeki ribayı ifade etmesi bakımından isabetli görülebilir. Ancak, daha önce de ifade edildiği gibi, ribanın yasaklanmasında asıl olan hasılat/sonuç değil eylemin bizzat kendisidir. Bu klasik tanımdan hareketle ribayı eylem olarak tanımlamaya çalışırsak şöyle bir durum ortaya çıkar: “هي المعاملة التي يشترط فيها الفضل الخالي عن العوض: Riba kendisinde karşılığı bulunmayan fazlalı̆̆ın şart koşulduğu işlemdir". Bunu bir aşama daha ileri götürerek ribayı iktisadî bir eylem biçimi olarak şu şekilde tanımlayabiliriz: " الربا: Riba nitelikleri aynı iki malın farklı miktarlarda değiştirilmesi eylemidir". Günümüzde çok sayıda değişik eylem ve yöntemle faizciliğin yapıldı̆̆ı dikkate alındığından bu şekildeki bir tanımın işin gerçeği ile daha örtüştüğü söylenebilir. Nitekim Allah'ın Elçisi'nden yapılan nakillerde riba çok farklı ve fakat tümü de haram nitelikli eylem ve maddi meblağlar için kullanılmıştır. Ancak şurası unutulmamalı ki, ribanın gerek tarihte gerekse günümüzde en fazla söz konusu olduğu eylem "kredi"dir; yani aynı niteliklere sahip iki malın farklı miktarlarda ve fakat belli vade ile değiştirilmesi işlemidir. Nitekim hadislerde de kredili/vadeli işlemlere vurgu yapılmıştır. Faiz/riba bu şekilde tanımlandığı ve finansal işlemler de bu yaklaşımla değerlendirildiğinde hangi işlemin faklı iktisadi değerlerin mübadelesinden ibaret gerçek ticaret, hangisinin de ticaret görüntüsüne büründürülmüş riba işlemi olduğu daha net olarak ortaya çıkacaktır.

\section{Sonuç}

Kur'an ve sünnette riba ayrıntılı olarak ortaya konulmuştur. Riba kelimesinin Kur'an ve sünnetteki kullanımı ona yüklenebilecek terim anlamı hususunda önemli ipuçları içermektedir.

Riba Kur'an'da sadaka, zekât, karz ve özellikle bey` ile mukayeseli şekilde ele alınır ve ribanın yapı itibariyle bu varlık transfer yöntemlerinden farklı olduğu vurgulanir.

106 Serahsî, el-Mebsût, 12/109. 
Riba tarihin her döneminde bilinen ve uygulanan bir yöntem olduğundan Kur'an'da ve sünnette kastedilen riba tarihi süreçte bilinen ve uygulanan ribadır. Ribanın Cahiliye (Kur'an ribası) ve sünnet (fadl) ribası şeklindeki ayrımını isabetli görmüyoruz. Zira nasslarda riba farklı yönleriyle bir bütün olarak ifade edilmektedir.

Klasik kaynaklarda riba genelde "muamelede şart koşulan karşılıksız fazlalık" yahut "karşılıksız fazlalı̆̆ın şart koşuldŭ̆u akit" şeklinde hukuki yaklaşımla tanımlanmıştır. Her iki tanımda da ribanın eylemsel yönüne değil hukuki bir bakış açısıyla hâsılat, fazlalık, sonuç tarafına vurgu yapılmıştır. Bu durum Batılı literatürde de benzer niteliktedir. Ribanın sadece fazlalığa yönelik hukuksal odaklı tarifi işin eylemsel tarafının gözlerden kaçması sonucunu doğurmuştur. Bunun bir neticesi olarak tarihte ve günümüzde çok sayıda işlemin özü itibariyle riba olmasına rağmen farklı ve masum ad ve kılıflarla uygulanması ve böylece insanlığın aldatılması durumu ortaya çıkmıştır.

Kanaatimizce riba hem -klasik kaynaklarda olduğu gibi- akit ve fazlalık olarak hukuksal açıdan hem de eylem türü olarak iktisadi açıdan tanımlanmalıdır. Hatta kendisi öncelikle iktisadi gaye ile girişilen iktisadi bir eylem olduğundan, eylemsel tarafı daha baskın olmalıdır.

Sonuç olarak ribanın farklı açılardan aşağıdaki şekilde tanımlanabileceği kanaatine ulaşılmıştır:

ktisadi eylem biçimi olması bakımından:

"الربا هي مبادلة المال بالمال متفاضلا: Riba nitelikleri ayn iki malın farkl miktarlarda değiştirilmesi eylemidir.",

ukuksal işlem bakımından:

:الربا هي المعاملة التي يشترط فيها الفضل الخالي عن العوض : Riba kendisinde karşılığı bulunmayan fazlalı̆̆ın şart koşulduğu işlemdir."

asılat/fark/sonuç olması bakımından:

:الربا هو الفضل الخالي عن العوض المشروط في المبالة، Riba mübadelede şart koşulan karşılıksız fazlalıktır" 


\section{Kaynakça}

Abdulbakî, Muhammed Fuad. el-Mucemü'l-müfehres. Kahire: 1996.

Aynî, Ebû Muhammed Bedreddin Mahmûd b. Ahmed b. Musa Hanefi. elBinaye fí şerhi'l-Hidaye. Beyrut: Dâru'l-Fikr, 1980/1400.

Azîzî, Muhammed Râmiz Abdulfettâh. Beyânu'l-hukmi'ş-şeri'yyi fi'l-fevâidi'lmasrifiyyeti redden alâ fetvâ. Amman: Mecmai'1-Buhûsi'l-İslâmiyye, 2003.

Bayındır, Abdulaziz. Ticaret ve Faiz. İstanbul: 2012.

Bayındır, Servet. İslâm Hukuku Penceresinden Faizsiz Bankacılık. İstanbul: 2005.

Behutî. er-Ravzu'l-murbi Şerhu Zâdi'l-Müstakni. thk. Muhammed Ahmed etTayyâr vd. Riyad: Dâru'l-Vatani, 2006.

Behutî. Şerhu Müntehâ'l-iradât Dekâiku uli'n-nühâ li Şerhi'l-Müntehâ. thk. Abdullah Abdulmuhsin et-Türkî. Risale, 2000.

Dârimî, Ebû Muhammed Abdullah b. Abdirrahman. Sünenü'd-Dârimî. nşr. Mustafa Dib el-Boğa. Dımaşk: Dâru'l-Kalem, 1991/1412.

Dıraz, Muhammed Abdullah. er-Riba fì nazari'l-kânûni'l-İslamî. y.y., ts.

Diwani, Tarık. Faiz Sorunu. çev. Mehmet Saraç. İstanbul: İz Yayıncılık, 2011.

Ebû Davud. Sünen. thk. Şuayb el-Arnavut - Muhammed Kamil Karabelli. y.y.: Risale nşr., 2009/1430h.

Ebu Zeyd, Abdulazim Celal. Fıkhu'r-riba. Beyrut: Müessesetür'r-Risâle, 2004.

Elmalılı, M. Hamdi Yazır. Hak Dini Kur'an Dili. nşr. İsmail Karaçam vd. İstanbul: 1992.

Erdoğan, Mehmet. Fıkıh ve Hukuk Terimleri Sözlü̆̆̈̈. İstanbul: 1998.

Ertürk, Kübra. Fikıhta Faize Konu Mallar. İstanbul: İstanbul Üniversitesi, Sosyal Bilimler Enstitüsü, Yüksek Lisans Tezi, 2018.

Gözübenli, Beşir. “İslâm'da Faiz Yasağı ve Paralı Ekonomi”. İslâm Ekonomisinde Finansman Meseleleri. 78-102. İstanbul: Ensar Neşriyat, 1992.

Hakim en-Nisaburî. el-Müstedrek. nşr. Mustafa Abdulkadir Ata. Beyrut: Daru'l-Kütübi'l-İlmiyye, 1990.

Hammad, Nezih. Akdü'l-karz fi'ş-şerîâti'l-İslâmiyye, Beyrut: 1991.

Hammûd, Sami Hasan Ahmed. "The İslamic Banking in Theory and Practic", Islamic Banking, İstanbul Bankası Spring Conferences-II .113-120. İstanbul: Büyük Tarabya Hotel, May 201982.

Hemşerî, Mustafa Abdullah. el-A'mâlü'l-masrafiyye ve'l-İslâm. Kahire: 1974. 
Hey'et. el-Mu'cemü'l-vecîz. Misr: 1980.

Hüseyin Tevfik Rıza, Rabevâtü'l-karz ve rabevatü'l-bey'. y.y.: 1998.

Ildız, Erkan. Eski Çă̆da Bankacılık ve Bankerlik. İstanbul: Türkiye Bankalar Birliği Yayınları, No: 297, 2013.

İbn Âşûr, Muhammed Tahir. Tefsîrü't-tahrîr ve't-tenvîr. Tunus: Dâru Tunûsiyye, 1984.

İbn Kayyım el-Cezviyye, Şemsüddin Ebu Abdillah Muhammed b. Ebi bekr. I'lâmu'l-muvakkî̂n an Rabbi'l-Âlemîn. thk. Muhammed Muhyiddin Abdülhamid. Beyrut: 1977.

İbni Abidîn. Haşiyetü İbni Abidin. Beyrut: Daru'l-Fikr, 1992.

İbni Hacer el Askalanî. Fethu'l-barî bi şerhi Sahîhi'l-Buhârî. nşr. M. Fuad Abulbaki. Beyrut: Dâru'l-Fikr, ts.

İbni Kudame, Muvaffakuddîn Ebû Muhammed. el-Muğnî. nşr. Abdullah b. Abdulmuhsin et-Türkî - Abdulfettâh Muhammed el-Hulv. Kahire: 1986.

İbni Nüceym, Zeynüddin Zeyn b. İbrâhim b. Muhammed Misri Hanefi. elBahrü'r-raik şerhu Kenzi'd-dekâik. y.y.: ts.

İbni Rüşd. Bidâyetü'l-müctehid ve Nihayetü'l-muktesid. Mısır: Matba'atü Mustafa Yay., 1981.

İbnu'l-Hümâm, Kemâleddin Muhammed b. Abdulvâhid. Şerhu Fethi'l-kadîr. 2. Basım. Beyrut: Dâru'l-Fikr, ts.

İlâhî, Fudayl. et-Tedâbîru'l-vâkıyetü mine'r-riba fi'-l İslâm. Riyad: 1986.

İsa Abduh. Bünûk bila fevâyid. Mısır: Dâru'l -İ'tisâm, 1977.

Kardâvî, Yusuf. Fevâidü'l-bunûk. Erişim 1 Temmuz 2003. www.islamnafatwa.com

Kâsânî, Ebû Bekir b. Mes'ûd. Bedâ'i'u's-sanâ'î' fî tertîbi'ş-şerâ'i'. Beyrut: Dâru'lKitâbi'l-İlmiyye, ts.

Kur'an-ı Kerim ve Meâli

Kurtubî, Ebu Abdullah Muhammed b. Ahmed b. Ebu Bekr. el-Camiu li Ahkâmi'l-Kur'ân. Beyrut: Müessesetü'r-Risale, 2006.

Küçükkalay, Abdullah Mesud. İktisadi Düşüncede Faiz: Antik Yunan'dan Monetarizm. İstanbul: Çizgi Kitabevi, 2018.

Kütüb-i Sitte.

Malik b. Enes. el-Muvatta. thk. Takıyyü'ddîn en-Nedvî. Dimaşk: Dâru'lKalem, 1991. 
Maverdi, Ebü'l-Hasan Ali b. Muhammed b. Habib. el-Havi'l-kebir hüve Şerhu Muhtasari'l-Müzeni. nşr. Ali Muhammed Muavvaz - Adil Ahmed Abdülmevcud. Beyrut: Dâru'l-Kütübi'l-İlmiyye, 1994/1414.

Mevsılî. el-İhtiyâr li ta'lîli'l-Muhtâr. thk. eş-Şeyh Zuheyr Osman el-Cuayd. Dâru'l-Erkam, ts.

Misrî, Refik Yunus. el-Cami fi usûli'r-riba. Dimaşk-Beyrut, 1991.

Haleva, Rov Yithsak vd. (ed.). Türkçe Çeviri ve Açıklamalarıyla TORA ve AFTARA: ŞEMOT, çev. Moşe Farsi. İstanbul: 2004.

Mütrek, Abdülaziz. er-Riba ve'l-muâmelatü'l-masrifiyye fi nazari'ş-şerîâti'lİslâmiyye. Kahire: 1974.

Nevevî, Ebû Zekeriyyâ Muhyiddin Yahyâ b. Şeref b. Nuri. el-Mecmu' şerhi'lmühezzeb li'ş-Şîrâzî. Beyrut: Dâru'l-Fikr, ts.

Özcan, Abdullah. el-Ecel fi'l-akdi'l-bey. Mekke: Ümmü'l-Kurâ Üniversitesi, Doktora Tezi, 1989.

Özsoy, İsmail. İslam İktisadında Faiz ve Ortaya Çıkan Problemler, İstanbul: İstanbul Üniversitesi, Sosyal Bilimler Enstitüsü, Doktora Tezi,1991.

Râzi, Fahruddîn Ebû Abdillah Muhammed b. Umer b. Huseyn el-Kureşî. Mefâtihu'l-ğayb et-Tefsîru'l-kebîr. Beyrut: Dâru İhyai't-Turâsi'l-'Arabî, 1934.

Saîdî, Ali b. Ahmed el-Adevî. Hâşiyetü'l-Adevî alâ Şerhi'l-Hıraşî. Beyrut: Dâru'l-Fikr, ts.

Semerkandî, Ebu Bekr Alâuddin Muhammed b. Ahmed. Tuhfetü'l-fukahâ. 2. Basım. Beyrût: Dâru'1-Kütübi'l-İlmiyye, 1993.

Seyyid, Muhammed Murteza. Tâcu'l-arûs, Mısır: Matbaatü'l-Hayriyye, 1306/1888.

Subhanî, Azeemuddin. Divine Law of Riba: New Critical Theory. Kanada: Montreal, 2016.

Şâtıbî, Ebû İshâk İbrâhîm b. Mûsa b. Muhammed el-Girnâtî. el- Muvâfakât fi usûuli'ş-şerîati. Beyrut: Dâru'l-Ma'rife, ts.

Şirbînî, Şemsüddin b. Ahmed. Muğni'l-muhtâc ilâ ma'rifati meâni'l-Minhâc. Beyrut: ts.

Taberî, Ebû Cafer Muhammed b. Cerîr. Tefsîru't-Taberî: Câmiu'l-beyan fî tefsîri'l-Kur'ân. Beyrut: Dâru'l-Kütübi'l-İlmiyye, 1412/1992.

Tahâvî, Ebu Cafer Ahmed. Şerhu Müşkilü'l-âsâr. nşr. Şuayb el Arnavud. b.y.: Müessesetü'r-Risâle, 1994. 
Ünal, Halit. "Arâyâ". Tu rkiye Diyanet Vakfı Islậ Ansiklopedisi. 3/337.

Zekeriyyâ el-Ensârî, Ebu Yahya Zeynüddin Zekeriyya b. Muhammed b. Ahmed. Esna'l-metâlib şerhu Ravzi't-tâlib. nşr. Muhammed Muhammed Tamir. Beyrut: Dâru'l-Kütübi'l-İlmiyye, 2001/1422.

Zeyrek, İsmail - Mızırak, Zekeriya. "Faiz Teorileri Üzerine Bir İnceleme: Finansal İstikrarsızlık Hipotezinin Temel Dayanağı". Selçuk Üniversitesi S.B.E. Dergisi 22 (2009), 383-394. 